Portland State University

PDXScholar

11-10-1994

\title{
The Origins and Development of the Defense Forces of Northern and Southern Rhodesia from 1890 to
} 1945

Eugene Peter Jarrett Pomeroy

Portland State University

Follow this and additional works at: https://pdxscholar.library.pdx.edu/open_access_etds

Part of the History Commons

Let us know how access to this document benefits you.

Recommended Citation

Pomeroy, Eugene Peter Jarrett, "The Origins and Development of the Defense Forces of Northern and Southern Rhodesia from 1890 to 1945" (1994). Dissertations and Theses. Paper 4774.

https://doi.org/10.15760/etd.6658

This Thesis is brought to you for free and open access. It has been accepted for inclusion in Dissertations and Theses by an authorized administrator of PDXScholar. Please contact us if we can make this document more accessible: pdxscholar@pdx.edu. 
THESIS APPROVAL

The abstract and thesis of Eugene Peter Jarrett Pomeroy for the Master of Arts in History were presented on November 10, 1994, and accepted by the thesis committee and the department.

COMMITTEE APPROVALS:

Jon E. Mandaville, Chair

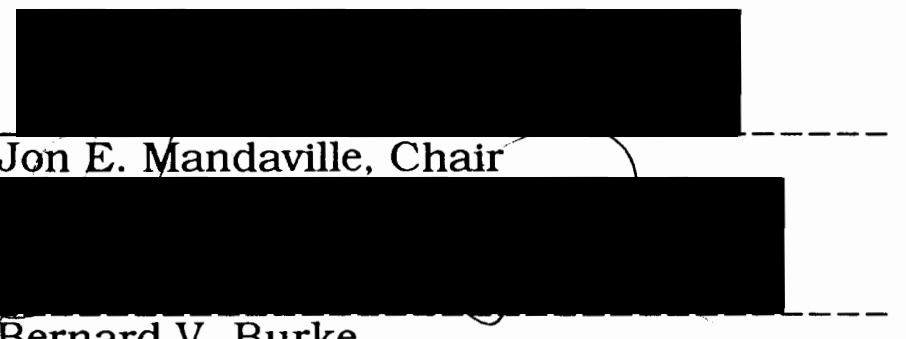

Bernard V. Burke

DEPARTMENT APPROVA

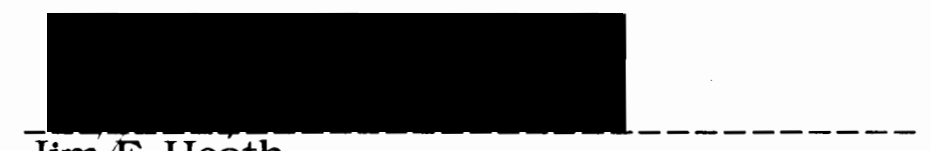

Jim F. Heath

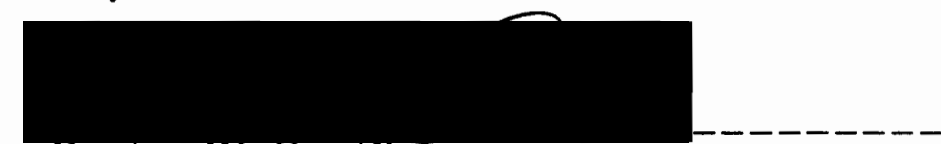

Burton W. Onstine

Representative of the Office of Graduate

Studles

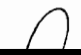

David A. John'son, Chair

Department of History

ACCEPTED FOR PORTLAND STATE UNIVERSITY BY THE LIBRARY

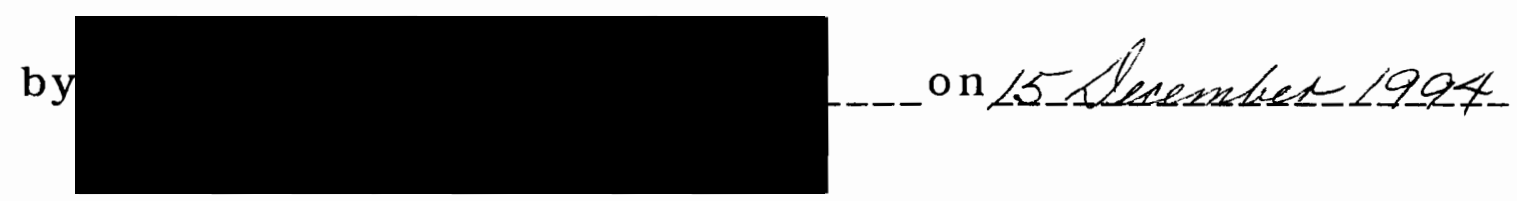




\section{THESIS ABSTRACT}

An abstract of the thesis of Eugene Peter Jarrett Pomeroy for the Master of Arts in History presented October 14, 1994.

Title: The Origins and Development of the Defense Forces of Northern and Southern Rhodesia from 1890 to 1945

This thesis examines Northern and Southern Rhodesia's history through the formation and development of their police and military units from the time Rhodesia was created in 1890 until the end of the Second World War. Southern Rhodesia, founded after a series of short and bloody frontier wars, was a self-governing British colony under a white minority and centered its peace-time security efforts around keeping an eye on potential uprisings from the African majority. White Northern Rhodesians viewed the African majority with similar suspicion although they were never able to exclude Africans from territorial defense. Northern Rhodesia was governed from London and ultimate power did not lie with the settler community.

The importance of the Second World War for Southern Rhodesia is that, because of British strategic policies, Rhodesians received perhaps the widest possible military exposure of any allied nation of the War. Because of a lingering hostility and suspicion by the Union of South Africa, Britain's prewar plans for defending their African empire were centered on making use of the skilled white manpower of 
Rhodesia and Kenya. Added to this was the willingness and apparent positive reception by white Rhodesians of black units in the Southern Rhodesian army, a break with the exclusively all-white tradition that prevailed up until then.

The political capital accrued to Southern Rhodesia because of its close cooperation with Britain was perhaps the significant factor in the establishment of the Federation of Rhodesia and Nyasaland in 1953 which included Northern Rhodesia and Nyasaland. The Federation was Southern Rhodesia's supreme political achievement and the closest it came to legal independence and international respectability. 
THE ORIGINS AND DEVELOPMENT OF THE DEFENSE FORCES OF NORTHERN AND SOUTHERN RHODESIA FROM 1890 TO 1945

\author{
by \\ EUGENE PETER JARRETT POMEROY
}

A thesis submitted in partial fulfillment of the requirements for the degree of

MASTER OF ARTS

in

HISTORY

Portland State University

1994 


\section{DEDICATION}

I would like to dedicate this thesis to all of those people who assisted and encouraged me over the period I spent researching and writing. First I would like to thank the History Department at Portland State for showing me that formal learning can be fun, something that I had not experienced since kindergarten. Among those at PSU are Dr. Jon Mandaville, my advisor, and Dr. Jim Heath, whom I first spoke to about taking on the Master's program. A word of thanks to Dr. Lewis Gann of the Hoover Institution and Dr. Richard Wood of the University of Durban-Westville in South Africa. Thanks also to Colonel (Ret.) Curt Welch for his insights.

To my old comrade-in-arms Roger England in whose garret in Grimsbury, Oxfordshire, I lived for a year and a half. Many thanks to Anthea Bazin of the Oxford Academy who hired me and where I taught ESL for over a year allowing me to survive and complete my research. I would like to acknowledge the good people at the Banbury branch of the Oxfordshire County library system who bent over backwards to get those hard-to-find books. A mention to the nice ladies at the Grimsbury Post Office. Many thanks to Luanne Bradshaw \& family, my cousin Jade Collins and others who allowed me to sleep on couches and fed me from time to time when I was cold and hungry.

Last but not least, my Aunt, Catherine Pomeroy Collins, who never lost faith in me, a special word of affection and thanks for everything. To my parents, whom I love. 
TABLE OF CONTENTS

CHAPTER

PAGE

DEDICATION.. .1

I INTRODUCTION. 1

II IN THE BEGINNING .6

III SOUTHERN RHODESIA'S FIRST ARMY;

The British South Africa Police, 1890-1926

IV NORTHERN RHODESIA'S ARMY;

Origins of the Northern Rhodesia Regiment, 1891-1945..........28

V THE SOUTHERN RHODESIAN ARMY, 1926-1945...................40

The Defense Act of 1926...........................................................40

The Southern Rhodesia Staff Corps.........................................48

The Southern Rhodesia Council of Defense.........................50

VI STANDING GUARD;

African soldiers, the British Empire, and Southern Rhodesia. .53

The Royal West African Frontier Force and the King's African Rifles, 1800s-1945.

Failure of the All-White Army and

the Rhodesia Native Regiment, 1914-1918.......................59

The Rhodesian African Rifles, 1940-1945

VII THE ALLIANCE; Britain, Southern Rhodesia and the African Colonial Forces, 1935-1945.

VIII WHITE RHODESIAN UNITS IN THE SECOND WORLD WAR.......80 
IX THE QUEST FOR AIR POWER; the Rhodesian Air Force, 1934-1945.

$\mathrm{X} \quad$ DIFFICULT ALLIES; South Africa, Southern Rhodesia and the Second World War. 100

XI CONCLUSION; the Beginning of the End...................................120 


\section{CHAPTER I}

\section{INTRODUCTION}

In 1991 the RAND Corporation's Arroyo Center, which is funded by the United States Army as their research and development center, issued a report on the Rhodesian counterinsurgency campaign which began in 1972 and lasted until 1980 when white minority rule came to an end with the creation of Zimbabwe. The aim was to compare Rhodesia's experience with America's in El Salvador and Vietnam. What the authors found was that many of the strengths and weaknesses of the Rhodesians reflected much of what had been acquired before and during the Second World War. ${ }^{1}$

How was it that a small country in south central Africa, ruled by a small white minority, was able to do this? The fact that Rhodesia has passed into history does not diminish from its military accomplishments. ${ }^{2}$ From the arrival of the Pioneer Column in 1890 , defense, to a greater or lesser degree, concerned the settler community and their descendants.

This thesis follows the development of Southern Rhodesia's defense forces from the arrival of the settlers in 1890 until the end of

\footnotetext{
${ }^{1}$ For the sake of simplicity and brevity, 'Rhodesian' will always refer to the white population.

${ }^{2}$ The black-ruled nation now known as Zimbabwe was Southern Rhodesia from the 1890s until 1964. In that year Northern Rhodesia became Zambia and the 'Southern' prefix was dropped from Rhodesia's name. Nyasaland is now Malawi.
} 
the Second World War in 1945 at which time Southern Rhodesia was to enter a new era as the 'senior partner' of the Central African Federation. This study deals almost exclusively with the military aspects of Rhodesian history between 1890 and 1945 but does not attempt to find explanations for broader social and political developments which have been dealt with more extensively than here.

From 1890 until the defense buildup of the 1930s, Rhodesians' military fears and prejudices were, with the exception of the Boer War and First World War, primarily directed at the larger African population. After 1935 and the Italian invasion of Ethiopia, Southern Rhodesia entered a defense agreement with Britain which completely altered the focus and direction of Southern Rhodesia's defense force from the perceived internal threat to the wider external threat.

This study is divided up into headings according to the military unit being examined and attempts follows a chronological format inasmuch as that is possible. The original intent was to examine just the Rhodesian Army and its origins, but this proved to be impossible as the defense of Southern Rhodesia was largely in the hands of the territory's police until well after the founding of the army in 1926. Similarly, leaving out the air force, military developments in neighboring Northern Rhodesia, or the influence of the African Colonial Forces or the Union Defense Force would have left an incomplete picture. ${ }^{3}$

The controversial issue of having Africans serving in the armed

${ }^{3}$ The Union Defense Force was the Union of South Africa's armed forces. When South Africa became a republic in 1961, the name was changed to the South African Defense Force. It has undergone another name change, to the National Defense Force, since the advent of majority rule in April 1994. 
forces, a normal practice in the rest of colonial Africa including those territories with a significant settler population, specifically Northern Rhodesia and Kenya, was expressly forbidden in white-dominated Southern Rhodesia. The founding, disbanding and refounding of Southern Rhodesia's black forces will be examined as will the ideal and reality of having an all-white army in a country with a minuscule white population.

The other area that will be examined is the coming of the Second World War and its profound effect on Southern Rhodesia's military development. In the face of the potential Italian threat from Ethiopla, the territory's army and air force became an integral part of Britain's defense plans for Africa and both expanded enormously in scope and size to meet these demands. The territory also became one of the homes of the Empire Air Training Plan which trained thousands of British and Commonwealth air crew during the war.

The intimacy of Anglo-Rhodesian defense cooperation contrasts sharply with the hostility between the Union of South Africa and Britain during the prewar period. That Britain should have turned to South Africa for an alliance during this period seems to be highly logical except when one remembers that the Afrikaner-dominated Union was home to long and bitter memories of wars with Great Britain. The Afrikaners, having lost the military struggle for independence in South Africa, were now masters of the Union and for many of them Britain was still the enemy. This did not prevent Southern Rhodesia and the Union from cooperating once the Second World War broke out.

In 1945 Southern Rhodesia found itself in a very advantageous 
political position due primarily to its intimate military relationship with Great Britain before and during the war. Within ten years of the end of the war, Southern Rhodesia was to become the dominant partner in the Federation of Rhodesia and Nyasaland. ${ }^{4}$ As part of Britain's post-war strategy, the Rhodesia and Nyasaland Army (R\&N Army) and the Royal Rhodesian Air Force (RRAF) were included in British defense plans for the Middle East. This subsequent period is outside of the scope of this study, but will be frequently referred to. Britain was going through the process of reorganizing and then retreating from her empire during the height of the Federation. The final period began after UDI, the establishment of the Rhodesian republic and the Chimurenga War which saw the end of white rule and the establishment of Zimbabwe. ${ }^{5}$

The change in attitude about Africans, who were the primary focus of Southern Rhodesia's defense worries, came about as a result of the Second World War. It was a war, it seemed, in which all of the races of the British Empire came together to fight the twin evils of fascism and Japanese expansionism. Just as the emerging world order of the 1940s and 1950s gave Americans, and the rest of the Western World, a sense of opportunity, destiny and greatness, so too was Rhodesia caught up with euphoria for the future where everything was possible. Not only had Rhodesia taken on England's enemies as her

\footnotetext{
${ }^{4}$ The Federation of Rhodesia and Nyasaland, also known as the Central African Federation, was formed by uniting the self-governing colony of Southern Rhodesia, the British-ruled possessions of Northern Rhodesia and Nyasaland into a loose federal structure that lasted from 1953 until 1963.

${ }^{5}$ UDI, the Unilateral Declaration of Independence was declared by the Rhodesian Front government of Prime Minister Ian Smith on November 11 th, 1965. Rhodesia became a republic in 1970. Chimurenga is the Shona word for freedom.
} 
own, but Rhodesians seemed to have found a solution to the perennial and vexing problem of race relations. ${ }^{6}$ The following passage from the official war history of Southern Rhodesia, published shortly after the war, exudes this confidence. Optimism in the future and faith in the past shows on every page and there is an unshakable belief in the cause for which they fought and sacrificed:

For how has our own country come out of a struggle in which so much was given? Before the war "Rhodesian" was a word little used or understood elsewhere. Now it is arousing interest throughout the Commonwealth and the world. The great resources of the land are being assessed, its future planned in a manner that must benefit all the races living here. In helping to save freedom once again by the valor of arms, our fighting men have opened our country to new horizons and won wide experience, practical and spiritual, for the generation that must guide us out of our small estate into a great inheritance.

${ }^{6}$ "It was Lord Malvern (then Sir Godfrey Huggins, Prime Minister of Southern Rhodesia and later to become first Prime Minister of the Federation) who said: "England's wars are our wars," and it was the late Admiral Sir Campbell Tait, when Governor of Southern Rhodesia, who stated with naval precision: "We are all of one company." W.V. Brelsford, Handbook to the Federation of Rhodesia and Nyasaland, p. 666.

${ }^{7}$ J.F. MacDonald, The War History of Southern Rhodesia, 1939-45, Vol. 2, p. 673. 


\section{CHAPTER II}

\section{IN THE BEGINNING}

Southern Rhodesia's frontier period was as colorful, exciting and as controversial as the American frontier only shorter in duration. The pattern of occupation, native uprising and reconquest was compressed into an eight year period starting in 1890 , so that by 1898 Southern Rhodesia was firmly under the control of the British South Africa Company, the 'Chartered Company', which had been founded by Cecil Rhodes in 1889 for the express purpose of bringing the lands north of the Limpopo into the British Empire. By making British conquest a function of private enterprise, Rhodes was given a freer hand than if it had been undertaken by a reluctant British Government. However, as Britain had long experience with this kind of colonial money making venture, they did not grant a totally free hand to the Chartered Company.

Unlike the experience in other European countries where there was considerable government interference and control, British colonies were expected, for the most part, to look after themselves, to succeed or fail according to their own merits unless there was an overriding strategic reason for their maintenance and protection. The drain on the treasury during its colonizing efforts in Ireland in the sixteenth century had discouraged English, and later British 
governments from officially sponsored settlement schemes. ${ }^{1}$ The English hit upon the idea of privatizing colonial ventures; joint-stock companies and individuals were given land grants, which the Crown would protect against foreign aggression, but not financial failure. ${ }^{2}$ The Charter system of settlement was thus inaugurated, in which the Crown allowed the company to rule a territory. "Instructions" were provided for the colony's entire judicial, commercial, and administrative structure. This meant that English, and later the British, Governments could always ensure that English law was not being trampled on by some distant colonial despot.

It also meant that the colonies and settlements could and did go through some hard times in their early years, to include, in the case of the very early settlements in the Americas, starvation and the financial collapse of the chartered companies. The end result was that the economic and political base of the colonies, with experience and a little marketing salesmanship, became broader and undoubtedly more realistic than the colonies of the other European nations. ${ }^{3}$ For Britain the mere acquisition of territory was less important than the benefits

\footnotetext{
' 'Colony', 'plantation', 'native' and 'planting' first entered the English imperial vocabulary at this time. The Beginnings of English Colonization, The Cambridge History of the British Empire, Vol. 1, pp. 56-57.

${ }^{2}$ The Cambridge History of the British Empire, p. 77-78.

${ }^{3}$ "Jamaica was the first of our colonies to be planted and developed by the State, and the State had to learn by trial and error the business in which private enterprise was now fairly expert, but in which it had bought painful experience in the days of Virginia. When the course of the undertaking is compared with the contemporaneous story of Surinam, a surprising contrast is apparent. On the Surinam plantation there was no public expenditure, and the inhabitants, with some assistance from Lord Willoughby, quickly became self-supporting; neither is there any record of serious disasters during the formative period. In Jamaica, on the other hand, despondency and apathy overhung the colony like a cloud." The Beginnings of an Imperial Policy. The Cambridge History of the British Empire, Vol. 1, p. 232.
} 
accrued to the nation and her subjects in the pursuit of trade. In order to secure that, the rule of law had to remain as supreme as possible.

The settlers ultimately aspired to, and almost always got, territorial self-rule under the aegis of the British crown. As with British settler colonies since Jamestown, Southern Rhodesia was no different and self-government was granted to the Rhodesians in 1923. All internal power devolved from the parliament in Salisbury and the Governor ultimately became little more than a figurehead. The right to territorial self-defense was placed firmly in the hands of the Rhodesians.

The citizen militias that were raised to defend the early settlements against the native uprisings were part of this frontier tradition that has lost nothing in their drama with the passage of time. Historians of the American frontier will recognize the style and form, if not the context, of the central African frontier:

The Matabele War was fought by Rhodesian volunteers with one Imperial unit, the Bechuanaland Border Police. The volunteers were the Salisbury Horse, Victoria Rangers and Raff's Rangers operating in two columns, the Salisbury Horse and Victoria Rangers operating together as one column and Raff's Rangers and the Bechuanaland Border Police together as the other for the advance on Lobengula's kraal...

Southern Rhodesia's military lore and foundation myths, important elements in a nation's popular perception of itself, were enhanced by incidents like the last stand of the Wilson Patrol on the Shangani River in December 1893 against the retreating Matabele impis of King Lobengula, or the tales of bravery and isolation against overwhelming odds at the Alice Mine in Mazoe in 1896. Because of

\footnotetext{
${ }^{4}$ A Brief History of the Rhodesia Army, pp. 1-2.
} 
this frontier tradition, the idea of raising African units beyond what was necessary for the maintenance of law and order in the tribal reserves was anathema when the question arose in the First World War:

The risings of 1896-97 were still fresh in the minds of the settler community, which had been literally decimated by the Shona and Ndebele rebels. Large numbers of the Matabele Native Police had defected at the outset of the risings, sowing the seeds of mistrust at arming and training Africans for modern warfare. It was feared that African troops with their military training could form the deadly core of future risings. ${ }^{5}$

Despite this, an African battalion was raised but quickly disbanded at the end of the war. When the question arose again in the Second World War, the white manpower shortage and the passage of time allowed the military authorities in Southern Rhodesia to repeat the experiment and Southern Rhodesia broke with her short military past.

\footnotetext{
${ }^{5}$ Peter McLaughlin, Ragtime Soldiers, The Rhodesian Experience in the First World War, pp. 73-74.
} 


\section{CHAPTER III}

\section{SOUTHERN RHODESIA'S FIRST ARMY; \\ the British South Africa Police, 1890-1926}

The police forces of the British South Africa Company were formed for the express purpose of establishing Pax Britannica and all of its ramifications in the territories granted to Cecil Rhodes' and his associates. In Southern Rhodesia this force was the British South Africa Company Police which eventually became the British South Africa Police (BSAP). The BSAC was not allowed to raise a military force under terms of its charter with the result that in both Northern and Southern Rhodesia, police forces had a defense as well as a law and order role. In addition to this minor problem in semantics, the British did not exercise direct control over the Company's police in the early days. The result was conflict with the Africans and an international border incident with the Transvaalers.

When a territory was formed and brought under British rule, its police came under direct British control. It was always recognized that colonial police forces should uphold the law:

British colonial policy generally attempted to develop in colonies those institutions and organizations with records of success and acceptability in the United Kingdom. The authorities recognized that these might have to be modified to suit local conditions, but their aim remained to create institutions as largely British as possible. ${ }^{1}$

\footnotetext{
${ }^{1}$ Clayton \& Killingray, Khaki and Blue: Military and Police in British Colonial
} 
British colonial administrators drew from the experiences and traditions of the mother country where two distinct traditions had developed. The first is the English tradition where the policeman generally represents and is responsible to the local community in which he serves, protecting the citizenry from harm and catching criminals. He is also responsible for his actions and is in no way above the law himself.

This model depends on a public consensus and generally agreed norms of social behavior. The British accepted the necessity for modification of the concept for an interim period, hopefully short, as it was transferred to colonial possessions of different traditions and attitudes, at lower levels of political and social development. The imposition of a new and strange culture would require the constabulary concept to strengthen, in particular, its capacity to contain unrest and keep order; the forces, therefore, would need to make provision for occasional deployments in gendarmerie and frontier military roles. ${ }^{2}$

The police in British Africa came from the tradition that developed in Ireland with the Royal Irish Constabulary (RIC), which had strong military overtones. The chief difference between the English and Irish models were that the RIC existed as an extension of the central government rather than local authorities. Like many continental European police forces, this arrangement gave the force a paramilitary cast, and indeed the RIC, and later the Royal Ulster Constabulary (RUC), received military training.

A disproportionate number of colonial police officers, including a number of the best, were Irishmen. These two traditions and the RIC, might have been difficult to align; however, this was not the case. The various British-controlled Indian police forces, organized in a way incorporating elements from both these

\footnotetext{
${ }^{2}$ Clayton \& Killingray, Khaki and Blue: Military and Police in British Colonial
} Africa, pp. 5-6. 
traditions, were very successful. ${ }^{3}$

This was the model that prevailed in the police forces in British Africa. Americans are benefactors of the English rather than the Irish tradition, and a glance around the British Empire, and the states that emerged from it, will give a good idea as to which forces fall into one or other or a combination of these categories.

Like the other forces in Africa the British South Africa Police fell into the RIC/RUC category. However, the ideals of British policing were bound to clash with Rhodesia's frontier society. In its early days the Company's police force reflected the aspirations of the settlers and "...in 1914 the BSAP was still looked on as Rhodesia's first line of defense." rather than a purely Law-and-Order organization. Many Rhodesians came from South Africa and inherited a frontier tradition of hostility towards Africans. They were leery of having any African force around them, armed or otherwise, as was the case with the Northern Rhodesia Police which will be dealt with later.

When the Pioneer Column moved into what was to become Southern Rhodesia in 1890, it came not only as a vanguard of South African settlement, but it represented the desires and ambitions of a wealthy and powerful visionary, an unstoppable combination in those days:

[Rhodes'] column was well equipped, and combined the military technology of the South African backwoods with that of the industrial revolution. There were 84 great lumbering ox wagons to carry the pioneers and their belongings. Their crews were carefully trained to maneuver with military precision and form

\footnotetext{
${ }^{3}$ Clayton \& Killingray, Khaki and Blue: Military and Police in British Colonial Africa, pp. 5-6.

${ }^{4}$ Peter Gibbs, The History of the BSAP, Vol. 2, p. 100.
} 
mobile pivots to support mounted riflemen in the event of attacks by African warriors. There was also a traction engine, a steam-driven generator to operate an electric searchlight, machine guns and light artillery. Hence Lobengula, the ruler of the great Matabele warrior kingdom in what is now Rhodesia, hesitated to assault the column.

The Pioneer Column broke up when the flag was raised at Fort Salisbury in September 1890 and the British South Africa Company's Police "...which had been established on the lines of a British mounted infantry regiment..." had as its first commanding officer a seconded Lieutenant-Colonel from the 6th Inniskilling Dragoons, an Irish regiment which provided many military appointments in southern Africa.

Initially a detachment of 100 was enrolled, largely from the Bechuanaland Border Police, but the strength was subsequently increased for the march into Mashonaland to $500 .^{6}$

The ad hoc nature of the Company's police in the early days seems to be emphasized by the inconsistent numbers given in different sources as to its size and organization. In 1892 the company drastically reduced the size of their police force. ${ }^{7}$ The financial drain of the force on the Chartered Company and the 3,000 settlers was considerable, amounting as it did to around twenty percent of the white population. ${ }^{8}$ It was rearmed and rebuilt for the showdown with

\footnotetext{
${ }^{5}$ L.H. Gann, From Ox Wagon to Armored Car in Rhodesia, Military Review, pp. $63-64$.

${ }^{6}$ A Brief History of the Rhodesia Army, p. 1.

${ }^{7}$ Di Perna gives the numbers as going from 600 to 40 , Gibbs puts the numbers as 650 to 150 and A Brief History of the Rhodesia Army gives the numbers as 500 and 150 with a 40 man Town Police Force.
}

${ }^{8}$ Anthony Di Perna, A Right to be Proud, p. 19. 
the Ndebele (or 'Matabele' as the settlers called them) from amongst the settlers. A range of settler militia units were raised obviating the need for Imperial troops, which they did not want anyway "...because they feared interference in Company affairs." Despite a relatively clear field and the absence of British interference in their affairs, the grievances of the Ndebele against the early practices of the Company's police, were a factor that could not be disregarded if Rhodesia was to be a profitable and well run country. The hunter and famous tracker, Frederick Courtney Selous...

...described the complaints made to him by a Matabele induna, who spoke bitterly "...of the high-handed manner in which the Ama Policey Minyama, the 'Black Police', behaved to him and his people." To Selous, it was the over-zealous native police who were sent to the kraals to obtain native labor that brought on the uprising in Matabeleland. ${ }^{10}$

The absence of British units in the Matabele War of 1892-93 and the Mashona/Matabele Rebellion of 1896-97 may have meant that BSAC control over Southern Rhodesia was more absolute than it would have been had the British become involved, but it also meant that Southern Rhodesia's police would have to change. This finally happened in 1896 when Leander Starr Jameson, 'The Doctor', the Company's Chief Executive Officer, in a colorful reinterpretation of the corporate takeover, led seven-eighths of the Rhodesia Mounted Police “...on a buccaneering expedition which came to be known as the Jameson Raid, leaving no more than about 80 men to police the whole

\footnotetext{
${ }^{9}$ Anthony Di Perna, A Right to be Proud, p. 27.

${ }^{10}$ Anthony Di Perna, A Right to be Proud, p. 30.
} 
of Rhodesia."11 Their efforts to rewrite South African history failed miserably, and they were arrested on New Year's Day upon arrival in the Transvaal, then known as the South African Republic, and deported to England, bringing Rhodesia to the attention of the British Government in a none too positive light. In March of that same year, rebellion broke out in Matabeleland and while it ended in August with Rhodes' personally negotiating with the Ndebele Chiefs in the Matopo Hills, it meant a temporary end of Company control over Southern Rhodesia's police. In October the BSAP was founded from the Company's police and the rebellion, which by now had spread to Mashonaland, was dealt with and eventually put down by them a year later in 1897. The British Government took control of the BSAP reorganizing it into four divisions which they "...virtually imposed on the Company as a safeguard against a repetition of irresponsible adventures." ${ }^{12}$ It implemented a policy of recruiting from the British middle classes, ensuring a supply of quality men with no separate class distinctions. ${ }^{13}$ It was on the road to becoming a professional force according to the Irish model:

...expanded by recruitment from Britain and South Africa to a white force of some four or five hundred strong, backed by a force of similar strength of locally enlisted native policemen popularly known as "the Black Watch. ${ }^{14}$

${ }^{11}$ Peter Gibbs, The History of the BSAP, Vol. 2, p. 3.

${ }^{12}$ Peter Gibbs, The History of the BSAP, Vol. 2, p. 4.

${ }^{13}$ "Similarly the Southern Rhodesian civil service did not have the British Civil Service division into "Administrative Class" (equal socially to officers, university educated); "Executive" (equal to warrant officers and sergeants) and "Clerical" (ordinary enlisted men)." Letter from Dr. L.H. Gann, September 9th, 1994.

${ }^{14}$ Peter Gibbs, The History of the BSAP, Vol. 2, p. 4. 
Southern Rhodesia's police now followed a rather tortured administrative path. The "buccaneering" days of Jameson were over and between 1898 and 1909 there were what was described as "...three stages of transition..." in the life of the BSAP. ${ }^{15}$ The ResidentCommissioner of Southern Rhodesia and the Commandant-General of the BSAP became distinct offices but both were now "Imperial" or British officers with responsibility to London and there was only one police force in the territory. The Administrator of Southern Rhodesia, the Chartered Company's man on the spot, had control over the citizen volunteers, except when they went on 'active service', that is on military operations, and then they came under an officer appointed by the Commandant-General who had supreme military command and control of operations. ${ }^{16}$

The next stage went from 1904 until 1909. In 1905 the offices of Resident-Commissioner and Commandant-General were combined, giving Britain the highest degree of control over the political and military affairs of Southern Rhodesia that she was ever to exercise.

There now came into existence a second police force, the Southern Rhodesia Constabulary (SRC), which was established by the Police Ordinance of 1903. This force came under the control of a Superintendent appointed by the Administrator and it was controlled by the Attorney General. The SRC, formed by joining together the Town Police of Bulawayo and Salisbury in 1903, was dedicated to the

\footnotetext{
${ }^{15}$ Remarks on Report dated October 13th, 1911 by Inspector-General of Oversea Forces, p. 6. PRO DO 119/878.

${ }^{16}$ Remarks on Report dated October 13th, 1911 by Inspector-General of Oversea Forces, p. 6. PRO DO 119/878.
} 
mundane business of law enforcement in the small towns of Southern Rhodesia. ${ }^{17}$ Because it had no military functions, the British Government allowed the Chartered Company to control it. This was a civil police force in the true sense of the word and did not come under the Commandant-General of the BSAP, except if it was “...employed for military purposes then it was to come under such regulations as the High Commissioner might determine." 18

From 1909 onwards the duties of Commandant-General of the BSAP and Resident-Commissioner were still combined, but were limited in peacetime to "...the right of inspecting at all times any police or volunteer force." ${ }^{19}$ Imperial control was slipping away and there was no longer any 'immediate' command of the BSAP or control of either police or volunteers by the Resident-Commissioner “...except in the event of military operations when he assumes the chief command but not necessarily the immediate command, of any police or volunteers employed thereon." ${ }^{20}$ As a means of keeping an eye on the state of affairs in the tribal areas, the BSAP had become a more professional force:

[They] relied on a small, but capable, mounted police force

${ }^{17}$ Rhodesia had many aspects of a typical frontier society; "But there was already a surprising proportion of less worthy citizens; and the cases reported in those earlier days in the Bulawayo and Salisbury newspapers, of whites prosecuted for a colorful range of crimes bid fair to rival in number and variety the reports in the same papers today when the white population population is twenty times the size." Peter Gibbs' The History of the BSAP, Vol. 2, Ch. 4.

${ }^{18}$ Remarks on Report dated October 13th, 1911 by Inspector-General of Oversea Forces, pp. 6-7. PRO DO 119/878.

${ }^{19}$ Remarks on Report dated October 13th, 1911 by Inspector-General of Oversea Forces, p. 7. PRO DO 119/878.

${ }^{20}$ Remarks on Report dated October 13th, 1911 by Inspector-General of Oversea Forces, p. 7. PRO DO 119/878. 
which served as the country's first line of offense. The police, a highly professional body, built up an efficient intelligence network. The countryside was effectively controlled by posts and patrols, and the police relied on the principle of prevention instead of repression. At the same time, the Chartered Company instituted many administrative and economic reforms. These were so effective that there were no further armed risings. ${ }^{21}$

As a result, Southern Rhodesia was able "...to send the bulk of their fighting men out of the colony to fight on the British side during the [Boer War]...and the First and Second World Wars."22 The fact that the BSAP was still organized as a military unit was one of the problems that London, and later Salisbury, had to wrestle with. The paramilitary nature of the BSAP, and the fact that it ceased being the colony's first line of defense after 1926 when Southern Rhodesia's army was created, could only mean that the police's residual military functions would conflict with those of the army. When the SRC was absorbed into the BSAP and both were returned to Chartered Company control, "...the presumption that the BSAP was a military and not a civil force would not have died so hard, and the disruptive cleavage between Town and District would not have persisted as long as it did after the final amalgamation in 1909."23 This way of thinking also could only have a detrimental effect on the conduct of military operations if and when the police would have to work with the army and air force:

The BSAP, of course, looked on themselves even as late as 1950 as the first line of defense. Indeed mounted infantry drills were still being taught as part of basic training at the time. In fact, 63-72.

${ }^{21}$ L.H. Gann, From Ox Wagon to Armored Car in Rhodesia, Military Review, pp. 63-72.

${ }^{22}$ L.H. Gann, From Ox Wagon to Armored Car in Rhodesia, Military Review, pp.

${ }^{23}$ Peter Gibbs, The History of the BSAP, Vol. 2, pp. 17-18. 
then, they probably were numerically the strongest disciplined (white) regular force in the country although by now much more policemen than soldiers. ${ }^{24}$

However, aside from the problems associated with having their police force under British control, or with the dual nature of the BSAP, there was the fact that, as a financial proposition, neither of the Rhodesias were as financially successful as had been hoped. The police came under pressure to cut costs, but these propositions came into conflict with the goal of the settlers to have a force that reflected their desires and aspirations. In September 1904, Lord Milner, the High Commissioner in Cape Town, sent a letter to the Rhodesian Administrator, Sir William Milton which contained the following ideas:

Any retrenchment effected during recent years, has been chiefly at the cost of the BSAP and I do not think that the present expenditure on that force is excessive. ...In order to protect a settled white population a regular force always equipped and ready, which can be sent anywhere at short notice, is essential, and I think that the bulk at any rate of that force should be white. ...Having regard to the extreme gravity of the financial position. I am prepared to try the experiment of substituting 100 Basutos for an equal number of whites. ${ }^{25}$

The thought of having the force diluted of its white members was a little short of heresy to the settlers. The High Commissioner was proposing something that worked well in a territory with no settlers or, as was the case in Kenya, where white settlement had come as a peaceful afterthought to the establishment of British rule by British

\footnotetext{
${ }^{24}$ Letter from Colonel Welch dated August 28, 1993. As a Major in the Rhodesia \& Nyasaland Army, Curt Welch was the first Commanding Officer of 'C' Squadron, Rhodesian Special Air Service Regiment when it was reestablished in 1961 as a regular unit. Major Welch left Rhodesia in 1963 when the Federation broke up and completed his career with the British Army.

${ }^{25}$ Peter Gibbs, The History of the BSAP, Vol. 2, p. 18.
} 
and not settler forces. In Kenya the territory's military and police forces were neither controlled nor manned by settlers, but Rhodesia, or at least Southern Rhodesia, was conquered by settlers and was therefore 'White Man's Country'. There would be no compromising on the issue of arming Africans, or not having an indigenous white police force.

Even after the BSAP reverted to Company control, the British Government, as grantor of the Company's charter, insisted on retaining ultimate control with the appointment of an InspectorGeneral of Oversea Forces, General Sir Ian Hamilton, to report on the state of Rhodesia's defense. ${ }^{26}$ His 'General Observations' and the point by point response by the Dominion Office is a good illustration of the differences in attitudes about Rhodesia shown over the years between British Government officials and British soldiers. The soldiers are obviously sympathetic, and identify with Rhodesia:

Progress, activity, enterprise are in evidence everywhere throughout the domains of the British South Africa Company. Population multiplies, business booms. Only in the military sphere do these vivifying influences seem at present to hang fire. The armed force - the war strength - of the country is stagnant... ${ }^{27}$

The British politicians and civil servants were less impressed. The somewhat dry response by the Dominion Office, begins by stating that "...Sir Ian Hamilton presents an interesting picture left on his mind by a brief and much occupied visit of the conditions and prospects of Southern Rhodesia, which is not perhaps a wholly

\footnotetext{
${ }^{26}$ Peter Gibbs, The History of the BSAP, Vol. 2, p. 80 .

${ }^{27}$ Report by the Inspector-General of the Oversea Forces on Southern and Northern Rhodesia, p. 2. PRO DO 119/878.
} 
trustworthy basis for the recommendations which follow." 28

Only in a very few centers and districts have there been as yet enterprise and development. Rhodesia, and especially Southern Rhodesia, is making good progress... But it is hardly correct to speak of an inflowing tide of humanity and unprotected wealth. Further, I think the references to the stagnation of war strength and the simplicity of the problem, without some qualification, are misleading. ${ }^{29}$

The difference is never more striking than the contrast of opinion over the the threat of trouble from the Africans. British officialdom, even at this early stage, was beginning to show itself divided in its evaluations of the Rhodesians and their worth to the British. Sir Ian Hamilton continues:

...the first point I wish to put forward and to emphasize is my conviction that in no part of the British Empire does the true voluntary spirit, the individual readiness to bear arms, show up better than it does in the territories immediately south of the Zambezi. Equally am I convinced that nowhere in the world does a finer, more manly, and by nature more soldierly type of man exist than is to be found throughout Rhodesia. ${ }^{30}$

This seems to be the first evidence of the admiration that British soldiers have held for Rhodesians, of their military qualities and potential which became stronger with the passage of time. ${ }^{31}$

The African threat also comes in for differing interpretations, with Sir Ian Hamilton incorporating the Rhodesian point of view into

${ }^{28}$ Remarks on Report dated October 13th, 1911 by Inspector-General of Oversea Forces, p. 1. PRO DO 119/878.

${ }^{29}$ Remarks on Report dated October 13th, 1911 by Inspector-General of Oversea Forces, p. 2. PRO DO 119/878.

${ }^{30}$ Report by the Inspector-General of the Oversea Forces on Southern and Northern Rhodesia, p. 4. PRO DO 119/878.

31 "His men were all Rhodesians, tough, self-reliant and taciturn men to whom the open air life was second nature." Anthony Kemp, The SAS at War, 1941-1945, p. 21. 
his recommendations:

They retain a vivid recollection of the events of 15 years ago, and can tell the younger settlers at first hand how the pioneers of civilization in Rhodesia had to fight for their very existence, and how many families and individuals in outlying stations paid with their lives the penalty of relying too implicitly upon the assumed timidity or forbearance of barbarians. ${ }^{32}$

The Dominion Office response dismisses this assessment and with it the urgency that there should be greater preparedness on the part of Southern Rhodesia's administration in the face of the potential African threat:

I think, however, the Report exaggerates the danger of a possible rising. The Mashonas are not a fighting race. Unquestionably the Matabele have lost much of their fighting spirit since the rising in 1896 . They have no leader. There are, so far as I can learn, no ominous signs of unrest. On the other hand the relative strength of the white population has greatly increased. ${ }^{33}$

The conclusions of both sides are also different in emphasis and direction. Sir Ian Hamilton felt that "Every European male citizen of mature years should by law be compelled to bear his part in the defense of the country..." ${ }^{34}$ while the Dominion Office concluded, since most Rhodesians were frontiersmen anyway, that "...I do not see how these men can be expected to absent themselves for a period of training and to leave their wives and children and their farms

\footnotetext{
${ }^{32}$ Report by the Inspector-General of the Oversea Forces on Southern and Northern Rhodesia, p. 2. PRO DO 119/878.

${ }^{33}$ Remarks on Report dated October 13th, 1911 by Inspector-General of Oversea Forces, pp. 2-3. PRO DO 119/878.

${ }^{34}$ Report by the Inspector-General of the Oversea Forces on Southern and Northern Rhodesia, p. 16. PRO DO 119/878.
} 
practically unprotected." ${ }^{35}$ As a nation in an early stage of its development, expenditure on defense beyond what was already in place, was undoubtedly seen as extravagant. Even the possibility of a war against Germany, alluded to by Sir Ian and mentioned briefly in the response with the words that... "This is a matter for experts, and I submit it should be considered with the question of Protectorate defense after the Imperial troops are withdrawn from the Union [of South Africa] territories." ${ }^{36}$ There is no sense of urgency.

The Inspector-General's report for 1913 reported "...that the state of these forces, including the BSAP, was highly unsatisfactory." ${ }^{37}$ Part of the reason may have been the poor state of the force as a purely law enforcement agency, "It cannot be said that the British South Africa Police are as efficient as they might be as a civil force, however excellent they may be as a fighting force!" ${ }^{38}$ It should be added that white society in Southern Rhodesia was in no way comparable to the American West as a law enforcement problem. The white population was small, there was little corruption in the civil service and there was white solidarity in the face of the African majority. ${ }^{39}$ The British Government was preparing for the possibility of war with Germany and

\footnotetext{
${ }^{35}$ Remarks on Report dated October 13th, 1911 by Inspector-General of Oversea Forces, p. 15. PRO DO 119/878.

${ }^{36}$ Remarks on Report dated October 13th, 1911 by Inspector-General of Oversea Forces, p. 12. PRO DO 119/878.

${ }^{37}$ Peter Gibbs, The History of the BSAP, Vol. 2, p. 81 .

${ }^{38}$ Remarks on Report dated October 13th, 1911 by Inspector-General of Oversea
} Forces, p. 12. PRO DO 119/878.

${ }^{39}$ Letter from Dr. L.H. Gann, September 9th, 1994. 
the BSAP had to be prepared. ${ }^{40}$ "As a Chartered Company the British South Africa Company was not authorized by the British Government to maintain military forces..." ${ }^{41}$, but in time of war they could, and did come under Imperial control for this purpose. In the case of Rhodesia, it meant that control would be exercised over all of the uniformed forces of Rhodesia on both sides of the Zambezi.

As Southern Rhodesia moved increasingly out of its frontier period and towards the First World War, its police also settled down and became a force according to the Irish model. The appointment of Major-General Sir A.H.M. Edwards, a retired soldier and former Chief Constable of the Metropolitan Police, as London's police force is known, as Commandant-General and Colonel Essex Capell, as his second-in-command, who also came from a military and colonial police background indicated the shift towards a more professional approach:

[They]...brought a wealth of much-needed experience to the service of the BSAP...their preferment over even long-serving members of the force was in a very different category from those arbitrary appointments in the early days, which Rhodes had handed out indiscriminately to his influential friends. ${ }^{42}$

The outbreak of war with Germany saw Southern Rhodesia once more relying on the BSAP. The German garrison at Schuckmannsburg on the Caprivi Strip, the finger of German territory that stretched from the main body of the German colony of South West Africa to the

\footnotetext{
${ }^{40}$ Peter Gibbs, The History of the BSAP, Vol. 2, p. 81.

${ }^{41}$ James Lunt, Imperial Sunset: Frontier Soldiering in the 20th Century, pp. 297-298.

${ }^{42}$ Peter Gibbs, The History of the BSAP, Vol. 2, pp. 100-101.
} 
Zambezi and bordered both Southern and Northern Rhodesia was seen as the most serious threat. In August and September the BSAP and the Northern Rhodesia Police mounted an operation against the Germans that resulted in a bloodless victory and surrender of the twenty-eight man German force. ${ }^{43}$

The next, and more renowned, BSAP contribution was "Murray's Column" which was raised to fight the Germans on the Northern Rhodesia/German East Africa border:

The response was to raise what were called 'service companies', a force composed of a core of regular BSAP ('A' Company) with volunteers for active service from the Southern Rhodesia Volunteers (' $B$ ' Company). So hurried was this force's preparation that the men had no training; they were merely put through a shooting test. Although the training of the BSAP and the SRV was hardly adequate for a war against a sophisticated enemy like the Germans, 'A' Company was sped to Broken Hill in early 1915. From there the force, about a hundred strong, marched to Abercorn at an average of twenty-five kilometers a day over the five weeks needed for the journey. This was considered a prodigious feat, and the unit became renowned for its marching; General Northey, the officer commanding that operational zone, came to call it 'my light cavalry'. 'B' Company reached the north-eastern frontier via Beira, Chinde, the Zambezi and Lake Nyasa. ${ }^{44}$

Murray's Column was to suffer from the climate in what was to become Tanganyika and the German commander's strategy of tying down as many Allied soldiers as he could. General Paul von LettowVorbeck's strategy of drawing as many British and Imperial soldiers into German East Africa had a significant long term effect on Rhodesian military policy.

${ }^{43}$ Peter Gibbs, The History of the BSAP, Vol. 2, pp. 104-108.

${ }^{44}$ Peter McLaughlin, Ragtime Soldiers, The Rhodesian Experience in the First World War, pp. 25-26. 
From the end of the First World War onwards, the police was engaged in its law keeping and internal security role. While it remained the only large body of uniformed personnel within the colony, it came to be less of a military force than a police force, although it is clear that the line dividing the two was becoming more and more distinct by the 1920s. The country was secured by mounted police patrols who reported back to Salisbury:

It is clear from these surviving reports that the concept of the patrols was based on the still lurking fear of risings in the native reserves, and a continuing belief - fathered by perhaps by a subconscious wish - that even though the [First World] war was over the BSAP's role was as military as it was civil. Headquarters had already set a belligerent tone, by listing the information which was to be collected by the patrol: the position of native strongholds and the best way to reach them; suitable positions for advanced bases; plans of attack. ${ }^{45}$

The challenge for the BSAP was somehow to remain Southern Rhodesia's first line of defense, yet fully develop as a police force. From the evidence, a chief problem seems to have been the lack of a clear vision of what the force's primary mission was. Its civil role was undoubtedly influenced by its continuing paramilitary role, in that it had to keep an eye on the Africans in the tribal areas who were seen as the future source of any trouble. This dual nature continued to plague the police for a long time to come. While the army grew in stature and experience because of experience gained through the Second World War, the Malayan Emergency and deployments in support of British policy in the Middle East, the BSAP remained within the borders of Southern Rhodesia and wedded to its traditional role. The fact that it was eclipsed by the army whose mission was unambiguously military

\footnotetext{
${ }^{45}$ Peter Gibbs, The History of the BSAP, Vol. 2, pp. 163-164.
} 
did nothing to diminish the BSAP's own view of itself as Rhodesia's first line of internal defense. 


\section{CHAPTER IV}

\section{NORTHERN RHODESIA'S ARMY; \\ Origins of the Northern Rhodesia Regiment, 1891-1945}

Northern Rhodesia, like its namesake south of the Zambezi, was concelved of as another settler state. By 1923 Southern Rhodesia had fulfilled part of this vision by assuming self-government under settler rule. Northern Rhodesia, never able to indulge in the fantasy that it could become another dominion, as Southern Rhodesia was doing, became another territory ruled from the Colonial Office. As such, its defense needs clashed with settlers' fears and prejudices about armed Africans. As Northern Rhodesia was not as economically successful as Southern Rhodesia it could not ultimately afford the luxury of excluding Africans from the armed forces as their cousins were doing across the Zambezi.

Northern Rhodesia began its existence as the two territories, North-Eastern Rhodesia and North-Western Rhodesia, and was only joined into a single administrative unit in 1911. While the legal occupation of Southern Rhodesia was completed by 1891 , and the physical occupation completed by 1897, it was only in 1891 that the BSAC's charter was "...extended to give it power to administer the territory north of the Zambezi...". ${ }^{1}$ The Chartered Company did not actually take control of the area until 1895, which was being patrolled

\footnotetext{
${ }^{1}$ W.V. Brelsford, The Story of the Northern Rhodesia Regiment, p. 1.
} 
by military forces from the new British territory of Nyasaland. The suppression of the slave trade and the extension of the Pax Britannica in Northern Rhodesia was being done by forces "...raised with the help of the Indian Government, and, although it was under the Imperial Commissioner of Nyasaland, it was also responsible for the protection of the Chartered Company's area"

Few Europeans chose to settle in Northern Rhodesia, an indication that the centuries of widespread rural Anglo-Saxon, and general European, territorial expansion was coming to an end. Even though the white population of Southern Rhodesia doubled and, at times even exceeded the African population growth rate, it could never hope to match the white proletarian demography of, for example, New Zealand. Even South Africa, whose white population exceeds that of New Zealand, had an African demographic 'time-bomb' that would eventually make exclusive white rule impossible.

The establishment of the borders of Northern Rhodesia was accomplished not by settlers, but by BSAC officials and police who moved north from Southern Rhodesia and east from British Central Africa, which was later renamed Nyasaland. The Germans, Belgians and Portuguese were thus prevented from moving into the territory and "...Rhodes successfully enveloped his new slice of country..." The Northern Rhodesia Police reflected this lack of popular white settlement and it was, from its beginnings, a typical white-led force of askaris. It was formed by combining the North-Eastern

\footnotetext{
${ }^{2}$ W.V. Brelsford, The Story of the Northern Rhodesia Regiment, p. 3.

${ }^{3}$ W.V. Brelsford, The Story of the Northern Rhodesia Regiment, p. 1.
} 
Rhodesia Constabulary and the Barotseland Native Police which were merged in December 1912 to become the Northern Rhodesia Police (NRP). ${ }^{4}$ As the territory's only force, it performed, like the BSAP, a dual law enforcement and military role. The NRP took part in the campaign in German East Africa as an infantry battalion even while “...the Northern Rhodesia Proclamation No. 17 of 1912 made it clear that in case of war the force could be employed 'for police or military purposes' within certain defined limits." Because of its dual nature, the NRP maintained a Criminal Investigation branch, a Civil Police branch, and a Military branch until 1933 when the Northern Rhodesia Regiment (NRR) was formed from the Military branch.

As had been the case with the BSAP before the First World War, the military nature of the NRP was also seen as a liability by its Commandant-General and in 1919-20 he wrote that "In a military police force the members of which have to perform the double duty of a soldier and a policeman, it is extremely difficult to attain and maintain efficiency on both sides." The force "...while well up and instructed in military work and duties are, with a few exceptions, totally ignorant of the requirements, etc., of civil police work." would continue as a military force:

As far as one can foresee at the moment, the military portion of the force will, for some considerable time to come, be greater and have more responsibilities that the civil division in respect 298.

${ }^{4}$ James Lunt, Imperial Sunset: Frontier Soldiering in the 20th Century, pp. 297 -

${ }^{5}$ James Lunt, Imperial Sunset: Frontier Soldiering in the 20th Century, p. 298.

${ }^{6}$ W.V. Brelsford, The Story of the Northern Rhodesia Regiment, p. 64 .

${ }^{7}$ W.V. Brelsford, The Story of the Northern Rhodesia Regiment, p. 64. 
to maintaining law and order. This however, would be no excuse for neglecting to build up the latter, the value of which will each year become more marked as the territory becomes more civilized, and the number of European residents and settlers increases. As a matter of fact the work it has done and is doing already proves its raison d'etre. ${ }^{8}$

Northern Rhodesia was a frontier territory long after Southern Rhodesia had settled down to a more normal existence. "The gradual elimination of military ranks in the civil police and the substitution of civil police titles and grading is a subject that requires consideration." This reflected not so much a 'Wild West' situation, but a lack of money and the fact that Northern Rhodesia was an economic backwater. ${ }^{10}$ The economically unstable nature of Northern Rhodesia was reflected by the the continued existence of the NRP as a force which performed both police and military roles. After the separation of the military branch, the NRR continued to be administered under the Northern Rhodesia Police Ordinance of 1926, unlike the system in the British colonial forces in east and west Africa: ${ }^{11}$

...until 1937 the Northern Rhodesia Regiment had its own permanent staff of officers, men who never left the Regiment and who were not liable for secondment either back to Britain or to other colonial units. Their salaries were paid by the

\footnotetext{
${ }^{8}$ W.V. Brelsford, The Story of the Northern Rhodesia Regiment, pp. 64-65.

${ }^{9}$ W.V. Brelsford, The Story of the Northern Rhodesia Regiment, p. 65.

${ }^{10}$ See Gann's A History of Northern Rhodesia, Chapter 3 for a description of the territory's white frontier before the First World War and the state of its finances. "The only people who were looking toward the Colonial Office for their salvation were the Northern Rhodesian settlers. Their descendants might find their attitude incomprehensible, but in 1919 an Imperial solution seemed good sense; Northern Rhodesia could not possibly finance its own expenditure..." p. 182.
}

${ }^{11}$ James Lunt, Imperial Sunset: Frontier Soldiering in the 20th Century, pp. 298-299. 
territory and they appeared in the civil service staff list. ${ }^{12}$

Seconded British officers to the African colonial forces were paid up to three times their normal salary with the difference between their British Army pay and their pay in Africa coming out of the colony's exchequer. ${ }^{13}$ Northern Rhodesia's military situation made it unique among the African regiments. It was, in effect, Northern Rhodesia's army, not unlike the new Southern Rhodesian Army, whose primary loyalty and focus were local and not to distant bureaucrats in London. There does not, however, seem to be any indications that the the loyalty of the NRR Officers and NCOs was anywhere questioned by the British Government.

Unlike Britain's other colonial forces, both police and military to the north of Rhodesia, the appointment, selection and retention of personnel in the BSAC's uniformed services seemed to have been on an ad hoc basis. We find, in 1894, that British and Indian Army officers who are lent to the Chartered Company "...are allowed to volunteer for two years' service and at the end of this period, if their behavior has been thoroughly satisfactory, they receive an extra gratuity in addition to their pay."14

...[Military] personnel... were attached to the civil authorities. Later, many of these men were to transfer from the military to the police forces and still be under the authority of administrative, not police, officers. ${ }^{15}$

${ }^{12}$ W.V. Brelsford, The Story of the Northern Rhodesia Regiment, p. vii.

${ }^{13}$ Clayton \& Killingray, Khaki and Blue: Military and Police in British Colonial Africa, p. 146.

\footnotetext{
${ }^{14}$ W.V. Brelsford, The Story of the Northern Rhodesia Regiment, p. 4.

${ }^{15}$ W.V. Brelsford, The Story of the Northern Rhodesia Regiment, p. 5.
} 
It is worth noting that settlers on the African frontier were not necessarily different from settlers on the American frontier, where loyalties quickly became parochial and norms of behavior were not all genteel. Those familiar with the reputation of the 'Wild West' should feel at home with the following description of Kenya in the first years after the Great War:

Many of the new settlers were wild, on occasion not averse to a shoot-out with the police at closing time of the bars. Special precautions had to be taken in 1923 at the time of a wild project of a settler coup. ${ }^{16}$

The same applied to Northern Rhodesia, although, as previously mentioned, settler society British Africa was fairly law abiding. ${ }^{17}$ The Northern Rhodesians presented a special security concern for the Colonial Office, although it is not possible to see the settlers as being in any way subversive, nor is there any evidence, other than a British desire to bring the NRR into the family of colonial forces, was there a yearning to cast off the mother country. There certainly seems to have been a strong Rhodesian identity and nationalism the strength of which, even in hindsight, is not easy to calculate as it involved a number of qualities. ${ }^{18}$ However, a sense of British concern is evident in Major-General Giffard's report to the Colonial Office when he

\footnotetext{
${ }^{16}$ Clayton \& Killingray, Khaki and Blue: Military and Police in British Colonial Africa, p. 110, and in Elspeth Huxley White Man's Country, pp. 135-139.

17 "Northern Rhodesia lacked the aristocratic, pseudo-aristocratic, or Raffish element of Kenya. No 'remittance' men in Northern Rhodesia. Lusaka, Ndola, Livingstone never comparable to the Wild West or even the Kenya White Highlands." Letter from Dr. L.H. Gann, dated September 9th, 1994.

${ }^{18}$ See Anthony Di Perna, A Right to be Proud, and L.H. Gann From Ox Wagon to Armored Car in Rhodesia, Military Review.
} 
inspected the NRR in 1938. The policy of replacing the "nonregular", 1.e. Rhodesian, officers and NCOs with seconded British Officers and NCOs was taking place:

From the technical point of view, the Regiment has made a great advance, both in its training and in its administration during the preceding twelve months. I consider that the great credit for this achievement is due to Lieutenant-Colonel W.A. Dimoline, MC, and to the Officers and British Non-commissioned officers under his command. I desire to make special mention of the non-regular officers and British non-commissioned officers, who have loyally accepted the new policy of seconding officers and British non-commissioned officers from the Regular Army to the Regiment. The knowledge of local conditions and of the language possessed by these officers and British noncommissioned officers and their service generally, have been of the utmost value. ${ }^{19}$

The question of possible divided or subversive loyalties of the local white population also figured in the establishment of the Kenya Regiment. ${ }^{20}$

The Kenya Regiment had been raised in 1936 with two aims. One was to channel the military aspirations of Kenya's young whites into a unit specifically controlled by the War Office, rather than the looser catch-all Kenya Defense Force organization existing as a result of local legislation and which it was feared might be used as an agent for local white political aspirations. The other was to act as an officer or white NCOproducing unit for any expansion of the [King's African Rifles]. ${ }^{21}$

The selection of the name for the Northern Rhodesia Regiment is another area that seems to give an indication of how distinct the Rhodesians felt about their identity. One of the questions that was to $820 / 34 / 13$

${ }^{19}$ Inspector-General's Report on the Northern Rhodesia Regiment, 1938. PRO CO

${ }^{20}$ See Elspeth Huxley's White Man's Country, Vol. 2, pp. 137-139, and Chapters XVI onwards for an idea of incipient white "nationalism" in Kenya.

${ }^{21}$ Clayton \& Killingray, Khaki and Blue: Military and Police in British Colonial Africa, pp. 212-213. 
arise during the time that the NRR became a fully integrated member of the African Colonial Forces was what name Northern Rhodesia's battalion was to have. One view is that, given the unique nature of the evolution of the battalion, from police to military unit, it was a natural follow on that the word 'Police' should be replaced by 'Regiment' for the military branch, but no one is entirely clear.

The difference in name between the military forces of Northern Rhodesia those of the other East and Central African territories is probably due to the fact that right up until 1924 the territory was governed, not by the Colonial Office nor by the British Government, but by a Chartered Company...22

The attitude among whites in Northern Rhodesia was as hostile to the concept of armed Africans as was the Southern Rhodesia Government and maintaining a separate title was, undoubtedly, an expression of a nascent Rhodesian nationalism:

I do believe that the answer, as I see it, to the question is that up to the start of the 1939 war, Northern Rhodesia - like all the East African territories - was financially responsible for its own defense. Each territory was, really, self-contained and the cost to each for defense was just as much, or as little, as each country's Legislative Council liked to vote every year. There was no East African Command, no joint defense with each country paying a fixed annual contribution to a common pool. Therefore, I believe that the Northern Rhodesia view was that 'as we have to pay for a Regiment it's going to belong to us and be called by the name of the country that owns it and none of your East African King's African Rifles'. ${ }^{23}$

In 1938 the Regiment was reorganized by Major-General Giffard, the Inspector-General of the African Colonial Forces, under whose authority the NRR eventually came, on lines similar to the

\footnotetext{
${ }^{22}$ W.V. Brelsford, The Story of the Northern Rhodesia Regiment, p. 65.

${ }^{23}$ W.V. Brelsford, The Story of the Northern Rhodesia Regiment, p. 71.
} 
askari battalions in east and west Africa with its cadre coming from British regiments on fixed short term tours. This process extended over two or three years with most of the displaced personnel being absorbed into the administration of Northern Rhodesia or other African territories. ${ }^{24}$ Why the NRR should have maintained its unique position in the family of colonial units for so long is probably best explained by a traditional reluctance by successive British Governments to interfere in domestic colonial affairs, deference to Rhodesian sensibilities and possibly even a lack of money.

While Northern Rhodesia belonged to the South African settler tradition, inasmuch as most of its whites came from the south, its main attraction for settlers were the mines in the area known as the Copperbelt which bordered the Belgian Congo. The majority of Whites who moved there after the discovery of copper...

...were composed of all sorts and conditions of men - Texan drillers, hardbitten Afrikaners, Yugoslav timbermen, fitters and turners from South Africa, smeltermen from Wales, American construction experts with experience in the copper mines of Arizona or Latin America, Cornishmen and others. ${ }^{25}$

They were far removed from the upper-class image of Kenya's settlers, or the more diverse and solid middle class of the Southern Rhodesians. As an illustration of this, in 1931, some six years after the Colonial Office assumed responsibility for the territory, the Governor of Northern Rhodesia, Sir James Maxwell, chaired a commission that made a report to the Oversea Defense Committee on security 300-301.

${ }^{24}$ James Lunt, Imperial Sunset: Frontier Soldiering in the 20th Century, pp.

${ }^{25}$ L.H. Gann, A History of Northern Rhodesia, p. 209. 
problems in the Protectorate. ${ }^{26}$ The transient nature of its small industrial age population, dependent as they were on the world price of copper and whose racial attitudes were less than enlightened, did not make for an easily soluble security situation. The report, written during the Depression, went into considerable detail about the problems associated with Northern Rhodesia's small white population and their unwillingness to have either an African infantry battalion or dedicate the necessary valuable time and money in order to form an all-white reserve unit in a country where whites were thin on the ground. ${ }^{27}$ The Governor's report contains analysis that not only reflects opinions of the day, but points to some simple truths and administrative problems:

We are not prepared to disagree wholly with the view expressed by some of the witnesses that it is bad for the morale of a rapidly developing British colony that it should be entirely dependent for defense on African troops. We agree that when the European population has become stable, if it ever does, consideration should be given to the creation of a European defense force within the limits imposed by the financial circumstances of the territory. In the meantime we see nothing shameful in retaining as a form of insurance against possible trouble a small, highly efficient force, led by British Officers and Non-Commissioned Officers. ${ }^{28}$

The problems associated with establishing, what was then termed, a "European Defense Force" in the territory also spilled over into the realm of Imperial Defense planning. In the eyes of the Governor, the territory had an internal security problem that was

\footnotetext{
${ }^{26} \mathrm{CID}-\mathrm{ODC}, 638-\mathrm{M}, 1931$. PRO CAB 8/55.

${ }^{27}$ CID-ODC, 638-M, 1931. PRO CAB 8/55.

${ }^{28}$ CID-ODC, 638-M, 1931. PRO CAB 8/55.
} 
“...without parallel in the other African dependencies." ${ }^{29}$ Tribal

Africans presented an easily solved security problem which involved the simple movement of the forces of law and order to potential trouble spots. The quandary lay in the Copperbelt:

The mining area, however, provides a problem peculiar to itself, since disturbances may take place in which Europeans and Africans are involved simultaneously. There is a strong antinative feeling among a section of the European workers, and the outbreak of inter-racial riots (possibly started by an incident of such as a case of rape) is not impossible.

The growth of the trade union movement among the European workers with the latent possibility of strikes might well be another source of disturbance.

In either eventuality, the restoration of order would present a difficult problem. It would be impossible to employ either the native police or the Northern Rhodesia Regiment to suppress disturbances in which Europeans were actively engaged. ${ }^{30}$

These ingredients, aided by the reality that the world was in the middle of the Great Depression made for poor race relations and an internal security headache for the authorities in Northern Rhodesia. Northern Rhodesians' settler attitudes towards the NRR is expressed, very diplomatically, in the unit's official history:

...there was a good deal of opposition from certain elected members of the Legislative Council to the strengthening of the Regiment. The opposition was based on the feeling in certain quarters that it was wrong for Europeans and European industry to be dependent for protection upon an African regiment. It was more strongly voiced in Legislative Council during the debate in 1938 on the formation of the Northern Rhodesia Regiment's European Officer's and Non-commissioned Officer's Reserve, a vital step in the growth of the Regiment, that eventually passed and confounded the objectors by proving its necessity and value in $1939 .{ }^{31}$

${ }^{29}$ CID-ODC, 638-M, 1931. PRO CAB 8/55.

${ }^{30}$ CID-ODC, 638-M, 1931. PRO CAB 8/55.

${ }^{31}$ W.V. Brelsford, The Story of the Northern Rhodesia Regiment, pp. 73-74. 
39

The NRR and its development from police force to infantry regiment illustrates the conflict between imperial necessity, military common sense and settlers' fears. In Southern Rhodesia, the larger white population, and the fact that political power was concentrated in Salisbury and not London, meant that a decision about raising such a unit could be shelved for as long as the old fears persisted. However, when Southern Rhodesia first raised an African battalion, the Rhodesia Native Regiment (RNR) in 1916, it was an unqualified success. 


\section{CHAPTER V}

THE SOUTHERN RHODESIAN ARMY, 1926-1945

Between 1926 and 1939 Southern Rhodesia's Army developed from little more than a territorial militia of two under-strength infantry battalions, whose value as a national defense asset was viewed as secondary to the older and proven BSAP, into an integral part of British imperial strategy. In order to better understand the process that the Southern Rhodesian Army went through, it will also be necessary to examine the military developments in Britain's colonies in east and west Africa and how Southern Rhodesia complemented Imperial defense strategy in a modest but significant way. The Defense Act of 1926

Until 1926 the British South Africa Police was both army and primary law enforcement agency in Southern Rhodesia. The Southern Rhodesian Government was not satisfied with the system as it existed and, three years after the granting of self-government by the British in 1923 , took stock of its defense policies by enacting a comprehensive Defense Act that put Southern Rhodesia's defenses on a firm, but modest, statutory basis. The system that the new Government in Salisbury had inherited in 1923 was formed around the BSAP and a volunteer militia called the Southern Rhodesia Volunteers (SRV). Like the embryonic Rhodesian Army that was to follow, the SRV was based around a cadre of regulars, drawn mainly from the BSAP, who fulfilled 
the administrative function. The SRV harked back to an earlier era, with its definite Victorian frontier flavor, and was...

...organized into the Cadre personnel and three columns of 500 men each, and Rifle Companies. The Cadre personnel of a column consists of men trained in each arm of the service to which will be attached the fighting troops in time of emergency. The latter will be obtained from men who volunteer for service in time of emergency. ${ }^{1}$

The problem was that because of its voluntary nature, it was fundamentally unreliable, and probably of dubious quality, something that has always afflicted citizen militias. ${ }^{2}$ Given the history of Southern Rhodesia, and the frontier tradition of southern Africa, it was not something that the Government could ignore, and was reinforced by what appeared to be a somewhat jaded opinion of the young men of the day; "Efforts to get the youth of the Colony to realize their responsibilities in respect of military service have signally failed." Under the terms of the 1926 act, every male citizen between the ages of eighteen and sixty years was liable for military service in defense of the Colony in time of war. In peace time, every man between the age of twenty and twenty-four was liable to undergo military training with a stipulation that volunteers could join at eighteen. The thin spread of the white population was also taken into consideration and "...only a prescribed number in prescribed areas shall be called up each year.

\footnotetext{
${ }^{1}$ Southern Rhodesia Defense Bill Memorandum, 1926. PRO WO 32/14151.

2 "The collecting of the militia, depends entirely on the prospects of the day; if favorable, they throng to you; if not, they will not move." George Washington in History of the British Army, J.W. Fortesque, Vol. 3, p. 407.

${ }^{3}$ Southern Rhodesia Defense Bill Memorandum, 1926. PRO WO 32/14151.
} 
These prescribed areas will probably be the larger townships." ${ }^{4}$ At this time the annual training for those not called up, but liable for call-up, "...and resident within a ten mile radius of a Defense Force Rifle Range shall undergo a course of musketry in each year..." was seen as being sufficient to deal with any problems at the time.

Southern Rhodesia also laid the foundations for a military system that went beyond the establishment of four reserve rifle companies. Even the school system was brought into the equation:

Cadets have been included in this act. At the present time they are not provided for under any act and it is considered that they should now receive official recognition. The question of the age at which a Cadet should commence training has been the subject of correspondence and it is the opinion of the Director of Education that the present age of 12 should remain in force, as any alteration to a higher age would tend to the disbandment of smaller units such as Gatooma, Que Que, Enkeldoorn, etc. which was to be avoided.

Service will include the whole period a cadet is at school, and will be compulsory unless the parent or guardian objects thereto in writing. ${ }^{5}$

The Cadet Corps was eventually disbanded in 1968. The details of the Bill that were outlined to the British by the Rhodesian Attorney General Sir Robert Mcllwaine in 1925 and next year by the new Minister of Defense (\& Attorney General) Major R.J. Hudson in 1926 was a highly comprehensive set of instructions for the Colony's security. Administratively, nothing was left to chance or ad hoc solutions, and between 1926 and the formation of the Federation of Rhodesia and Nyasaland, the Act was amended four times.

${ }^{4}$ Southern Rhodesia Defense Bill Memorandum, Chapter 1, 1926. PRO WO $32 / 14151$.

${ }^{5}$ Southern Rhodesia Defense Bill Memorandum, Chapter 1, 1926. PRO WO $32 / 14151$. 
Despite a sometimes strained relationship between the BSAP and the Army in the years to come, the Act also provided for a working relationship between the two services. The new order founded the BSAP's Reserve and Field Reserve, which cleared up concerns that a new military organization might compete for Southern Rhodesia's limited white manpower:

One of the objections brought forward to the British South Africa Police forming the Permanent Force is that the members available to take the field are too [few]. The Field Reserve does away with this obligation. A further argument advanced is that it is dangerous to remove police from their districts in time of emergency. The British South Africa Police Reserve does away with this obligation. Both Field Reserve and British South Africa Police Reserve will consist of members of the British South Africa Police. ${ }^{6}$

The paramilitary nature of the BSAP, its continuing dual role meant that in the years to come, a rivalry of sorts would grow up between the two services. In the 1930s this would become so pronounced that it became one of the reasons for the setting up of Southern Rhodesia's Council of Defense in 1936 when, for the first time, the small defense establishment, by now consisting of an embryonic air force and British South Africa Police, coordinated policy with the politicians. ${ }^{7}$

Nothing was to be left to chance. In his communication to the British, Hudson defined Southern Rhodesia as a British Dominion, a distinction that was to be ultimately compounded by the creation of what can best be described as a pseudo-Dominion, the Federation of $32 / 14151$.

${ }^{6}$ Southern Rhodesia Defense Bill Memorandum, Chapter 2, 1926. PRO WO

'Letter from H.J. Stanley to the Secretary of State for Dominion Affairs, No. 339, Confidential, 10 th July 1936. PRO CAB $21 / 642$. 
Rhodesia and Nyasaland, "...I may point out that Canada, Australia, New Zealand and the Union of South Africa, have all adopted the principle of compulsion." He was not blind to the demographic realities facing Southern Rhodesia, and undoubtedly the shadow of the struggles of the 1890s hung over his thoughts:

...the need for compulsory training is, I think, more urgent than that of the first three named countries. We have in this Colony a comparative handful of Europeans living in the midst of a very large native population. Under present conditions the preponderance in numbers of natives over Europeans is increasing. If a serious native rising should occur - and that is the only eventuality against which we must prepare - every able bodied European in the districts affected, and probably in the whole Colony will be called upon for service at short notice. It is necessary, therefore, that steps be taken to train as large a proportion of the population as we can. I am convinced that no system of purely voluntary training will achieve this result, there will always be a large number of young men who for various reasons will not submit themselves to training, however willing they are to serve in time of War.

It would be inaccurate to assume that everyone in any position of authority in Africa blithely assumed that political change would never come to the British Empire. Hudson's statement, while reflecting a view of what the past was capable of, also had a sense of what the future might bring. This was the time when India was beginning its transition to independence and old certainties were beginning to be questioned. Five years after Southern Rhodesia's Defense Act, the Governor of Northern Rhodesia, Sir James Crawford Maxwell, in a report to the Committee for Imperial Defense-Oversea Defense Committee (CID-ODC) in London described the defense prospects

\footnotetext{
${ }^{8}$ Sub-enclosure II to Dispatch no. 281 from the Government of Southern Rhodesia dated 14 September 1925, Cost of Administrative Report Defense Paragraphs: 314-319, 363-380, memorandum by the Minister of Defense, Major R.J. Hudson, MP. PRO WO 32/14152.
} 
Northern Rhodesia. It included these less than confident words about the future:

Southern Rhodesia has made up its mind for better or for worse to create a European colonization within the Tropics. It is moving, with what eventual success it is difficult to foresee in view of differing opinions, towards the establishment of a stable polity. It anticipates its children and grandchildren and greatgrandchildren will make their homes in a colony which the present generation has founded and it is attempting to approximate as far as possible to the self-governing dominions lying within the temperate zone. ${ }^{9}$

Up until this point, the external defense of Southern Rhodesia, as shown by the record of the Boer War and the First World War, had been adequately met by a massive turnout of volunteers. While this may have been adequate and admirable in order to fight "England's enemies" beyond her borders, the Southern Rhodesia Government realized that, for a multitude of reasons, not least of which was the one described in the Memo to the British Government, the status quo would have to change.

The men who went to the war were frequently a larger percentage of the white population than was the case with the other British Dominions. That this phenomenon was “...probably attributable more to the nature of the Southern Rhodesian economy (i.e. predominately agricultural and extractive), from which it was easier to withdraw manpower, than, say, the industrial economy of Britain, ${ }^{10}$

\footnotetext{
${ }^{9}$ CID-ODC, 638-M, Report of Defense Commission for Northern Rhodesia, under the chairmanship of Northern Rhodesian Governor, Sir James Crawford Maxwell, 1931, Item 33. PRO CAB 8/55.

${ }^{10}$ Britain's armed forces absorbed $11 \%$ of the population, Canada's $9.6 \%$, Australia's $13.6 \%$, the Gold Coast's $1.8 \%$. Peter McLaughlin, The Thin White Line: Rhodesia's Armed Forces since the Second World War, Zambezia (1978), Vol. VI (ii), p. 176.
} 
than to overwhelming patriotism." ${ }^{11}$ is probably not a fair assessment of individual Rhodesian motivations but it does point out that the Rhodesian economy, emerging from the Depression and with a potential abundance of African labor, would not miss them.

One thing is certain and that was that the long peace that ensued can only have tempered Rhodesian fears about having armed Africans in the Defense Force. However, the establishment of the Rhodesian African Rifles was, at this point the farthest from anyone's mind and will be dealt with later.

The effectiveness of the BSAP in keeping Southern Rhodesia quiet also meant that the Southern Rhodesia Volunteers, like all volunteer citizen militias, was of inconsistent value, and they were so viewed in Southern Rhodesia. Major Hudson not only realized that the nature of the SRV was inadequate to the task of defending against a native uprising, but noted that the attitude of the citizenry towards volunteering was less than enthusiastic:

A further objection to the voluntary system is that it is not a fair one - the drudgery and burden falls on the keen and conscientious men and those whose sense of duty is not so strong, escape. ${ }^{12}$

As it turned out, the peaceful nature of Southern Rhodesia in the 1920 s precluded the Government from turning it into a Sparta on the veld despite ongoing government concerns:

...it is proposed to enforce full training in the three towns of

${ }^{11}$ Peter McLaughlin, The Thin White Line: Rhodesia's Armed Forces since the Second World War. Zambezia, Vol. VI (ii), p. 176.

${ }^{12}$ Sub-enclosure II to Dispatch no. 281 from the Government of Southern Rhodesia dated 14 September 1925, Cost of Administrative Report Defense Paragraphs: 314-319, 363-380, memorandum by the Minister of Defense, Major R.J. Hudson, MP. PRO WO 32/14152. 
Bulawayo, Salisbury and Umtali only. So far as the rest of the Colony is concerned, it is proposed to make it compulsory for all men of the prescribed age who reside within ten miles of a rifle company to join that company and complete the prescribed course of musketry each year. I do not think this would be too onerous an obligation and there should be little, if any, objection to it. $^{13}$

The Rhodesia Regiment (RR) was thus established as a Territorial force, or a permanent reserve unit, despite some reservations about the worth of of the young generation, and its presumably inadequate sense of duty. ${ }^{14}$ Four rifle companies were set up within a framework of two battalions, and were spread across the country. The first battalion was established in Salisbury at company strength and the second battalion, also at company strength, was formed in Bulawayo. The second, or ' $\mathrm{B}$ ' Company, of both battalions were formed in Umtali and Gwelo respectively by the next year. ${ }^{15}$ The Southern Rhodesia Staff Corps

The Staff Corps was established in 1926 as the Permanent Staff Corps and was the only group of Regulars, or Permanent Force

\footnotetext{
${ }^{13}$ Sub-enclosure II to Dispatch no. 281 from the Government of Southern Rhodesia dated 14 September 1925, Cost of Administrative Report Defense Paragraphs: 314-319, 363-380, memorandum by the Minister of Defense, Major R.J. Hudson, MP. PRO WO $32 / 14152$.

14 "In addition to its necessity for the military requirements of the Colony, compulsory training will, as pointed out by Mr. Moffat, be advantageous to the young manhood of the country. I have spoken to many persons on this point, there seems a general consensus of opinion that a large proportion our young men are lacking in discipline and sense of duty. Military training will, undoubtedly, tend to remedy these defects. Personally I do not think we should estimate its value in this respect too highly but in the opinion of many who are more competent than I am to judge, compulsory training will have a very great effect in improving the young men of the Colony." Subenclosure II to Dispatch no. 281 from the Government of Southern Rhodesia dated 14 September 1925, Cost of Administrative Report Defense Paragraphs: 314-319, 363- 380 , memorandum by the Minister of Defense, Major R.J. Hudson, MP. PRO WO 32/14152.
}

${ }^{15}$ A Brief History of the Rhodesia Army, p. 8. 
members, in the Southern Rhodesian Army. The Permanent Force consisted of men drawn mostly from the BSAP, with a headquarters instructional and administrative staff consisting of six officers and twenty-one warrant officers and non-commissioned officers. This headquarters unit was the beginning of the permanent Staff Corps and was entirely administrative. ${ }^{16}$ The chief problem with this organization, which would only become evident once the Federation of Rhodesia and Nyasaland was established, was that it was not the 'brain' of the armed forces. It was not a body with an intellectual tradition that could objectively identify strategic problems facing Southern Rhodesia, or the Federation, and offer objective strategic military solutions that the politicians could use. The army of a minor selfgoverning colony with less than thirty regular soldiers and four companies of citizen soldiers, whose priorities in life were far removed from the ones envisaged by the Minister of Defense would have to have had very perceptive leadership to predict what the future would bring. Intellectually and emotionally the new Rhodesian Army was probably more of a reserve unit for the British Army than an army in its own right.

This was partly due to the nature of Southern Rhodesia which had no intellectual tradition; it had no university until after the Second World War. By way of contrast, South Africa has had universities since the early nineteenth century and a strong and influential intellectual tradition.

The result was that the Staff Corps was little more than a

\footnotetext{
${ }^{16}$ A Brief History of the Rhodesia Army, p. 7.
} 
training cadre for basic infantry tactics. Doctrine was based on the wars of the 1890s with modern technology and organization taking the place of the inspired armed settler. The new regular soldiers, most of whom had military experience, were drawn from the BSAP and formed the instructional and administrative nucleus of the Army until the expansion of the Second World War and the advent of the Federation after it. Other than identifying the problem, that is, the need to counter native uprisings, no preparation was made to equip the new Army with an organizational or intellectual framework that could identify and examine wider strategic problems. The Staff Corps never fulfilled that role, and nowhere is there evidence that it did. The result was two-fold. The presence of instructors, NCOs whose quality seems to have reflected comparable standards in the British Army "...were quite capable of commanding rifle companies and were doing so within three or four years of the new army's formation and battalions and brigades within eight to ten years." ${ }^{17}$ This made sense as the the Rhodesia Regiment was little more than four regionally based infantry companies, and the structure of the BSAP was based on small units of men operating alone in the tribal areas. "But of most of the officers there is something different to say."

The intellectual quality of the more senior officers of the Rhodesian armed forces prior to and during Federation was low, their millitary interests parochial and combat experience at unit level very limited. The handling of formations on operations was an unknown science. Early on the staff system, such as it was, chiefly served a static geographic spread by an admixture of BSAP and civil service procedures. Occasionally small scale field deployments arose during Camps of Training for members of the RRR [Royal Rhodesia Regiment] fulfilling their annual obligations. Potentially enlivening links with other armies and

\footnotetext{
${ }^{17}$ Letter from Colonel Welch dated August 28, 1993.
} 
overseas courses were severely restricted probably on financial grounds but also, I suspect, on account of inertia and an almost total absence of professional interest. Not for no reason was the Permanent Staff Corps as it was sometimes called nicknamed [sic] the Permanent Sports Club! Its members were indeed distinguished in that field if no other. ${ }^{18}$

The faults in the system were thus laid down early, and while the experiences gained by Rhodesians during the Second World War, and the influx of immigrants after it, greatly benefited the Federal Army and presumably the army of the breakaway Rhodesian republic. "The main point here is that the driving force for modernization and awareness of the needs of the future came from the bottom and not from the top." ${ }^{19}$ It was the kind of flaw that an army of such a country could not afford to have.

The Southern Rhodesia Council of Defense, 1936

From the establishment of the Defense Force in 1927 until 1936, the BSAP and the Army had two separate commanders. However, when the Commanding Officer of the Army retired, the BSAP Commander was appointed as Acting Officer Commanding Southern Rhodesia Forces and all units of the Defense Forces were brought under one command. "It is thought that the present system should lead to smoother working and should bring the various units, Permanent and Non-permanent closer together."

In addition to securing a greater measure of cooperation between the units of the Force the following advantages have been achieved:-

(a) The Minister is brought into closer and more satisfactory

\footnotetext{
${ }^{18}$ Letter from Colonel Welch dated August 28, 1993. “...it was not unknown for quality junior NCOs (who had held commissions in the British Army) to be instructors on officers' tactics courses."

${ }^{19}$ Letter from Colonel Welch dated August 28, 1993.
} 
contact with the whole Force.

(b) The OC [Officer Commanding] has a better peacetime knowledge of the Forces he will command in war time and accordingly, can secure a greater measure of coordination in the training of all units.

(c) Some measure of economy has been obtained by the elimination of one senior officer from the military command.

(d) Policy under one commander is facilitated and the requirements of all units can be presented to the Government through one channel, thus eliminating the competitive element in securing funds. ${ }^{20}$

In May 1936, Southern Rhodesia established a Council of Defense composed of the Prime Minister, the Minister of Defense, and the heads of the different military organizations and the British South Africa Police "...to consider the Defense problems of the Colony and advise the Government on such matters as may be placed before it." In short, the council was to have functioned as Southern Rhodesia's political and military brains for the formulation of military policy, and the closest thing to a General Staff that the Defense Forces were to have. It was not a system that was continued and by the time of Federation had been abandoned.

Their aims were to secure greater cooperation between the various units, bring the Prime Minister and Defense Minister into contact with them, coordinate policy, and eliminate "...the competitive element in securing funds." With the retirement of the Army Commander, the Police Commander was made Acting Officer Commanding of the Army. This 'measure of economy' brought the Army and Police under one Commander for perhaps the only time in its history. The first meeting also established the Southern Rhodesian Air Unit on a formal, but humble basis.

${ }^{20}$ Letter from H.J. Stanley to the Secretary of State for Dominion Affairs, No. 339, Confidential, 10th July 1936. PRO CAB $21 / 642$. 
The document went on to spell out in some detail what the military establishment of Southern Rhodesia looked like and the coordination that was taking place with the Imperial Defense Committee in London. This was the run up to General Giffard's arrival on the scene and his proposals to the Rhodesians which turned Southern Rhodesia's defense establishment into an adjunct of Britain's armed forces. Because of these arrangements with Britain, the statement in the Defense Council document that "The OC lOfficer Commanding] has a better peacetime knowledge of the Forces he will command in war time..." was to never take place during the Second World War, or any other conflict until after UDI. 


\section{CHAPTER VI}

\section{STANDING GUARD; \\ African soldiers, the British Empire, and Southern Rhodesia}

One of the most important military developments for Southern Rhodesia was the military relationship with Britain's African Colonial Forces in the years leading up to the Second World War. The African Colonial Forces encompassed all of the armed forces north of the Zambezi River, to include the Northern Rhodesia Regiment, and south of the Anglo-Egyptian Sudan. The benefits that were to come from this alliance between the small Rhodesian community and the military forces of ten African colonies and possessions were far reaching.

In the waning years of the nineteenth century, both Britain and the British South Africa Company had installed themselves in east and south-central Africa within a few years of each other. Their first actions were to set up authorities that would enforce laws and maintain peace in the new territories. Whether it was the establishment of a new settler community in the heart of Africa, or the suppression of the slave trade, the immediate need was to raise an armed force of some description that would not be a financial burden to the British taxpayer.

The Royal West African Frontier Force and the King's African Rifles

The British colonies and protectorates in West Africa were the the Gambia, Sierra Leone, the Gold Coast, and Nigeria. Unlike east 
Africa, where British colonization began late in the nineteenth century, British association and possession, in some cases, dated back to the sixteenth century, if only as trading stations, and their military organizations laid claim to a longer association with the British. One example given shows the metamorphosis from hired watchmen, of possible dubious value, to famous regiments:

...the Oil River Irregulars and possibly better known by its nickname, 'the Forty Thieves'; in 1891 its title was changed to the Niger Coast Constabulary, and in 1900 to the Southern Nigeria Regiment, West African Frontier Force. ${ }^{1}$

The transition from paramilitary watchmen to bona fide military units took longer than in east Africa. The West African Frontier Force (WAFF) was established in 1897 and brought the various forces in west Africa under a unified command with its own Inspector-General. British officers and NCOs were sent from British regiments on a voluntary basis to the WAFF for tours of duty of a fixed length. ${ }^{2}$

In the east African territories the rule of the Imperial British East Africa Company, another chartered company, was so short and unsuccessful as to be insignificant in their development as British possessions. In British East Africa, which became Kenya and Uganda after the First World War, and Nyasaland, various military units were either raised locally or recruited in other British territories. In January 1902, following the example of the WAFF, Nyasaland's Central African Rifles, the East African Rifles, in what became Kenya, and the Uganda Rifles were brought together as battalions of the King's African

\footnotetext{
${ }^{1}$ James Lunt, Imperial Sunset: Frontier Soldiering in the 20th Century, pp. 174175.

${ }^{2}$ James Lunt, Imperial Sunset: Frontier Soldiering in the 20th Century, p. 175.
} 
Rifles (KAR). ${ }^{3}$ Like the WAFF, the KAR had its own Inspector-General, and its various battalions came under a unified command with British officers and NCOs being seconded on a voluntary basis. ${ }^{4}$ As with so many military forces in colonies around the world, the line between police and military duties during those early days were blurred. ${ }^{5}$

British Somaliland came under British control in 1885 because of its strategic position at the mouth of the Red Sea. It first came under the Foreign Department of the Government of India, as did those British protected-territories on the Persian Gulf and on the periphery of south Arabia. ${ }^{6}$ In 1898 The Foreign Office took over from the Indian Government, and in 1905 the Colonial Office was given the final responsibility for the territory. ${ }^{7}$

The Somaliland Camel Corps (SCC) was raised in 1914 to fight against Mohammed bin Abdulla Hassan, known to the British as the "Mad Mullah." After a twenty year campaign (1900-20) of considerable

${ }^{3} 1$ st and 2nd Battalions were from Nyasaland, 3rd Battalion was from Kenya, 4th and 5th from Uganda, and 6th was raised for service in Somaliland. The number of battalions rose and fell depending on the economic and political situation. When the KAR was disbanded at the end of British rule there were seven battalions. Clayton \& Killingray, Khaki and Blue, pp. 200-201.

${ }^{4}$ The Inspector-General "...was charged with advising the government departments concerned, ...the Colonial Office and the War Office..." and three, later four, colonial administrations in East Africa. "He was also responsible for inspecting the various units and had authority to issue directions. In the event of operations, whenever two or more KAR battalions were involved he would exercise overall command. It was not an easy assignment” James Lunt, Imperial Sunset, p. 206.

${ }^{5}$ Clayton \& Killingray, Khaki and Blue, pp. 79, 109-1 10.

${ }^{6}$ Aden, Kuwait, Gatar, Bahrein, Oman and the Trucial States (today's United Arab Emirates). Aden was under the only British possession, the rest were protected states. Ravindar Kumar, India and the Persian Gulf Region, pp. 1-20.

${ }^{7}$ The Foreign Office was responsible for all Protectorates, the Colonial Office for the Dominions and Colonies. Starting in 1880, Protectorates began to be transferred to the Colonial Office. The Cambridge History of the British Empire, Vol. III, p. 742. 
ferocity in which the Mullah's forces showed great military skill, the British were victorious only because the Mullah died of sickness in $1920 .^{8}$ The SCC came under the organizational umbrella of the KAR in 1923, and, in 1940 at the outbreak of the war with Italy, consisted of fourteen British officers, 400 askaris $^{9}$, and 150 reservists in two Camel Companies, two Pony Troops and a rifle company from $1 \mathrm{KAR}^{10}$ Nyasaland had supplied an extra company since 1922 when a company of the SCC had refused to put down a disturbance which resulted in the death of a British officer. ${ }^{11}$ Being a part of the KAR was not a popular idea with the Somali askari, who are a cultural part of the Moslem Arab world. ${ }^{12}$

Like the KAR battalions and companies in east Africa, the Royal West African Frontier Force (RWAFF), as it became in 1928, could be moved between the various possessions, when needed, to support one

\footnotetext{
${ }^{8}$ Captain Adrian de Wiart, later to win a VC and become a Lieutenant-General, wrote, "In spite of many expeditions against him had evaded capture, and when he was finally defeated by airplanes I felt a sense of real personal loss. He was a Godsend to officers with an urge to fight and a shaky or non-existent bank balance." James Lunt, Imperial Sunset, p. 250.

${ }^{9}$ Askarl comes from the Arabic word for army, 'askar. In the context of Africa, it refers to African soldiers who are led by European officers and NCOs.

${ }^{10}$ James Lunt, Imperial Sunset: Frontier Soldiering in the 20th Century, p. 258. N.B. ' 1 KAR' is the shorthand description of the First Battalion, the King's African Rifles. This method is used in the British Army and will be used throughout this study.

${ }^{11}$ James Lunt, Imperial Sunset: Frontier Soldiering in the 20th Century, p. 253.

12 "...there were also disciplinary troubles when the [71st KAR] battalion was raised, the Somali soldiers demanding Indian style uniforms rather than KAR, and in the event receiving most of it; their objections included that of being treated as "Christians and East Africans." Clayton \& Killingray, Khaki and Blue, pp. 268-269.
} 
another. ${ }^{13}$ The African Colonial Forces were not organized like the Indian Army, which was a separate organization from the British Army, and where the British officers would spend their entire career. Senior British NCOs and officers were supplied by secondment, usually for a renewable two and a half year tour after a long home leave. ${ }^{14}$ The Sudan Defense Force had its origins in Britain's relationship with Egypt and will not be dealt with. ${ }^{15}$

When the question of raising units like the KAR arose in the Rhodesias, the answer from the settlers was always an emphatic no. As we have seen, the prime concern of the 1926 Defense Act was the possibility of a native uprising; "Outnumbered thirty-six to one, was it sensible to arm and (even more importantly) train a unit that could provide a hard core of disciplined leadership for insurrection?"16 However, what we find in Northern Rhodesia and Southern Rhodesia is a clash between two British colonial traditions which, over time, gave rise to the hybrid that became the Rhodesian Army. The frontier military tradition was essentially the militia system, the

${ }^{13}$ Unlike the KAR, the RWAFF contained battalions that took the name of the territories they were based in, i.e. the Nigeria Regiment, the Gold Coast Regiment, etc. James Lunt, Imperial Sunset, p. 175. 218-219.

${ }^{14}$ James Lunt, Imperial Sunset: Frontier Soldiering in the 20th Century, pp.

${ }^{15}$ The Sudan Defense Force was founded in 1925 after a mutiny of Egyptian and Sudanese soldiers, which arose from a dispute between Britain and Egypt over the Sudan. The SDF was controlled by the Governor-General of the Sudan, who in turn came under the Foreign Office, and not the Colonial Office, a simpler structure than the African Colonial Forces. Unlike the African Colonial Forces, where all officers were British, the SDF had Sudanese officers, which meant that the British officers were older and more senior than KAR and RWAFF officers and tours were longer. Because of the Egyptian and Ottoman connection, all rank titles were in Turkish. James Lunt, Imperial Sunset, pp. 277-279.

${ }^{16}$ Owen, The Rhodesian African Rifles, p. 1. 
citizen in arms which goes back to the Middle Ages. English colonial governments had always found it cheaper, and possibly more convenient politically, to have a citizen militia composed of settlers ready to be called upon in an emergency, than a body of professional soldiers, loyal to the mother country, costing money and, to complicate things, misbehaving in their free time. The militia tradition held sway in Southern Rhodesia until the reality of its small white population, the harshness of the climate, especially to the north of the Zambezi River, and the fact that Africans were more than willing to volunteer, forced them to change and incorporate elements of England's other colonial military tradition.

This other tradition had its origins in the practical need to protect British economic and strategic interests in areas which were not particularly healthy for Europeans, such as east and west Africa, home to the KAR and RWAFF, the Caribbean and India. The highest expression of this process was the British Indian Army, whose origins were as the army of the East India Company, a completely separate organization from the British Army, in which British officers served for their entire professional careers. In Africa, as we shall see, the union of these two English traditions, the settler militia and the native soldiers led by white officers came together, clashed and resolved themselves in Northern and Southern Rhodesia.

Failure of the All-White Army and the Rhodesia Native Regiment, $\underline{1914-1918}$

Factors that led to the establishment of Southern Rhodesia's first black unit, were the necessity of war, the African climate and, the willingness of the Africans living in the Reserves to join up and fight 
the Germans. Until the First World War, the Southern Rhodesians followed the pattern of the other, all-white British Dominions and raised units composed exclusively of whites to fight the King's enemies. "There was traditional White suspicion of Black troops and the creation of more Black units [was seen] as a potential Pandora's Box, even though these troops have been consistently loyal throughout the country's history." 17

The raising of the RNR and the debate that was to ensue about the merits of training Africans, was linked to the fate of the Rhodesian volunteers who answered the call to arms in 1914. The high casualty rate of the First World War affected the small white population of Rhodesia as much as it did anyone else. The difference was that the the white population base was considerably smaller than any of the other territories that aspired to or had achieved nationhood. Not only were Rhodesians serving in Europe, but one of the two all-white, battalion-size infantry units, the 2nd Rhodesia Regiment, was almost decimated by the campaign in German East Africa.

The ranks of the all-white (South African, Rhodesian \& British) and Indian Army units in east Africa were ravaged not so much by the German commander, General Paul von Lettow-Vorbeck (whose use and leadership of his Schutztruppe showed that African soldiers could be loyal and effective) but by the unhealthy climate of Tanganyika, as German East Africa became after the First World War. ${ }^{18}$ The 2nd

\footnotetext{
${ }^{17}$ Peter McLaughlin, The Thin White Line: Rhodesia's Armed Forces since the Second World War. Zambezia (1978), Vol. VI (ii), p. 178.

18 "As a result 12,000 South Africans were sent home. Replacements had to be found from somewhere." Major J.R. Sibley, Tanganyikan Guerrilla, East African Campaign 1914-1918, p. 115.
} 
Rhodesia Regiment had to be disbanded in early 1917 because of disease: "Fewer than seventy men could answer roll call among the 2nd Rhodesians, although more than one thousand troops had passed through their ranks in various drafts." ${ }^{19}$

The medical statistics of 2nd Rhodesia Regiment speak for themselves. There were 2,272 admissions to hospitals and 10,626 cases of sickness. The regiment had 1,038 men pass its ranks during its East African campaign war. This meant that on average every man went to hospital twice and reported sick ten times. Periodically the regiment, with a nominal strength of 800 , was reduced to an effective combat strength of less than 100; when it was pulled out of East Africa in January 1917 there were only 91 men fit for duty. The Germans had not killed the 2nd Rhodesia Regiment, disease had. ${ }^{20}$

White Rhodesians had originally hoped to form a Regiment that would be deployed to the Western Front as a single national unit, as the other dominions were doing. The closest they came to realizing this was their 'adoption' of the King's Royal Rifle Corps (KRRC), a British light infantry regiment. ${ }^{21}$ The reasons for Rhodesians going into the KRRC are not clear, but it may have had to do with its reputation as an elite unit, its frontier origins or the fact that the KRRC had no overt county associations as was, and frequently still is, the case with most British regiments. While Rhodesians served in

${ }^{19}$ "Really," wrote Smuts to a colleague, "this is not a country into which to bring a force of white men." Charles Miller, Battle for the Bundu, The First World War in East Africa, pp. 232-233.

${ }^{20}$ Peter McLaughlin, Ragtime Soldiers, The Rhodesian Experience in the First World War, p. 41.

${ }^{21}$ The 60th, or Royal American Regiment, was raised to fight the French in North America during the Seven Year's War but never served in America during the War of Independence. It became the King's Royal Rifle Corps (with two battalions) in 1881. It survives today as the Royal Green Jackets, after it merged with two other light infantry regiments in 1957. 
almost every unit and branch of service in the British forces, the KRRC seemed to offer them a home, so much so that all-Rhodesian platoons were formed. ${ }^{22}$

As infantry on the Western Front, Rhodesians discovered that war in the twentieth century was not something that the Colony's small white population could sustain:

Once the unit was thrown into Flanders it rapidly began to suffer casualties; at times the toll of dead and wounded was so great that the Rhodesian platoon virtually ceased to exist. But it was always resurrected by fresh recruits from Rhodesia....But throughout the war replacements posed a problem. The platoons would be suddenly exposed to sharp, murderous bouts of action which all at once decimated them, and the steady but small flow of recruits often took months to reconstitute them. The 2 nd Rhodesia Regiment died a long, lingering death, but the Rhodesian platoons in Europe died many times over, rising Phoenix-like each time. ${ }^{23}$

Rhodesians who had been in the 2nd Rhodesia Regiment, and then went to serve with the 3rd South African Infantry Brigade on the Western Front found that "...the war was more deadly and relentless, and the troops found that they had left one hell-hole for another. ${ }^{24}$ The Rhodesians came back home with new perceptions:

Of the 5,716 [white Rhodesians] who served during the Great War over 700 were killed, or died of wounds, disease and other causes. This was over twelve percent of the total in dead alone. ${ }^{25}$

The casualty rates alone demonstrated that Southern Rhodesia could not sustain large all-white national units. However as Southern

${ }^{22}$ Peter McLaughlin, Ragtime Soldiers, pp. 49-50.

${ }^{23}$ Peter McLaughlin, Ragtime Soldiers, pp. 50-51.

${ }^{24}$ Peter McLaughlin, Ragtime Soldiers, pp. 51-52.

${ }^{25}$ Peter McLaughlin, Ragtime Soldiers, p. 140. 
Rhodesia had experienced trouble in its efforts to convince Africans to join the Rhodesian economy, the feeling was that they should not be urged to join up. There was competition for African labor, especially in the mines and on the farms and, not unnaturally, the BSAC and the rising manpower needs of the war clashed:

The Administrator, Sir Drummond Chaplin, wrote of Southern Rhodesia's manpower problem in 1917: 'I am afraid we have about come to the end of the men whom we can send to the war from this Territory. We shall be able to raise another native contingent, and we may get a platoon or two for the 2 nd Rhodesia Regiment, but that is about all. We must keep the mines going and retain adequate protection or something like it, to deal with any possible local trouble. ${ }^{26}$

Africans were originally recruited in 1915 as drivers for the Army or as 'scouts' for the 2nd Rhodesia Regiment. In 1916 a decision was finally made to raise an African regiment since, besides the already mentioned drain on the colony's white manpower, the BSAC was ready to knock over the sacred cow of all-white fighting units:

In addition, the Administration decided to abandon the 'unwritten code' in the face of German 'treachery' in using African troops. As the Rhodesia Herald put it in a report sounding remarkably like an advertisement for a lonely hearts club: "Natives accustomed to life in the bush were wanted to meet similarly skilled natives acting in concert with the Germans, and in response to a demand for such men the native of Rhodesia flocked willingly to the colors anxious to show their loyalty to the King." 27

The Rhodesia Native Regiment began life as an Ndebele unit because it was felt that their warlike reputation (they are an offshoot of the Zulu nation) would make them a natural choice as soldiers.

\footnotetext{
${ }^{26}$ Peter McLaughlin, Ragtime Soldiers, pp. 73-74.

${ }^{27}$ Peter McLaughlin, Ragtime Soldiers, p. 74.
} 
However, while recruiting was eventually extended to other African groups in Southern Rhodesia the main source of recruits came from outside of the Colony (the Shona hid from recruiters fearing that they would be conscripted). When the second battalion of the RNR was raised in 1917 the recruiters concentrated on African migrants from north of the Zambezi, so that by 1918 seventy-five percent of the 2,360 who had passed through its ranks came from beyond the borders of Southern Rhodesia. ${ }^{28}$ The practice of drawing from as many of the ethnic or tribal groups as possible from which to fill the Colony's defense force meant that no one group would dominate or subvert the loyalties of its members, and the regiment became the askaris' primary focus of loyalty. This was a common British practice, with notable exceptions like the Gurkha regiments in India, throughout the empire.

In Northern Rhodesia, the question of whether or not to maintain an African battalion came up against the territory's demographic and economic realities. The all-white Northern Rhodesia Rifles, originally the Northern Rhodesia Rifle Association, was raised in October 1914, issued with rifles, but no uniforms; “...their only distinctive military insignia being a badge in the form of a hartebeeste's head with the letters "N.R.R." ${ }^{29}$ and marched from the rail line to the border with German East Africa, some 550 miles away. ${ }^{30}$ By October of 1915 , the unit was disbanded and the men were

\footnotetext{
${ }^{28}$ Peter McLaughlin, Ragtime Soldiers, pp. 74-75.

${ }^{29}$ W.V. Brelsford, The Story of the Northern Rhodesia Regiment, p. 35.

${ }^{30}$ W.V. Brelsford, The Story of the Northern Rhodesia Regiment, p. 29.
} 
dispersed to other units in Africa or went to join the British Army in Europe. "As was to be expected of such a force, composed of tough, independent-minded settlers, relations between them and the more regular forces were sometimes not all they should be." ${ }^{31}$

They possibly were a tough, awkward lot to handle, but their qualities of individualism and leadership were obviously wasted so long as they were employed as a unit and would be better employed by individuals taking the lead in other units. ${ }^{32}$

In any case, the men of the Northern Rhodesia Rifles returned from their short but not undistinguished war in rags and by 1925 the unit had ceased to exist even as a reserve unit. ${ }^{33}$ The hope among settlers in Northern Rhodesia that their territory would follow Southern Rhodesia's constitutional path was stillborn and the fate of its short lived all-white unit was a faint echo of military developments south of the Zambezi.

The Rhodesians and the South Africans had felt that the conflict in Africa should be a 'White Man's War'. This idea had first come about during the Boer War when neither side, except for an occasional lapse, had used African soldiers. Given the small size of German forces in east Africa, this unwritten 'code' was disregarded by them and it soon became obvious to everyone that Africans made excellent soldiers who could put up with the climate in German East Africa. The Germans added insult to injury by integrating settlers into the all-black, whiteled Schutztruppe in east Africa which did not happen in South West

\footnotetext{
${ }^{31}$ W.V. Brelsford, The Story of the Northern Rhodesia Regiment, p. 35.

${ }^{32}$ W.V. Brelsford, The Story of the Northern Rhodesia Regiment, pp. 35-36.

${ }^{33}$ W.V. Brelsford, The Story of the Northern Rhodesia Regiment, p. 36.
} 
Africa. The First World War in Africa became a war, with the previous exception, between black soldiers led by white officers. Not only was the WAFF brought in from west Africa, but the KAR was expanded and the NRP became, despite its name, a fully-fledged infantry battalion of askaris. Southern Rhodesia was also brought into the equation, much to her discomfort, by the creation of the RNR:

General Northey [commander of the Northern Rhodesia Police] who was fighting the Germans along the Northern Rhodesia/Nyasaland border and whose fully stretched troops were being daily depleted by sickness got wind of the rumor and immediately let the War Office know that he could certainly do with extra African troops from Southern Rhodesia. ${ }^{34}$

The RNR served against the German Schutztruppe with great success and distinction, but it was rapidly disbanded, in December 1918, at the end of hostilities.

It is sad to record that though the King had seen fit to permit the use after the surname of the initials of distinction won, the [British South Africa Company] Administration, shamefully, issued a directive that the Askaris, having endured so much, were to be discouraged from doing so. ${ }^{35}$

\section{The Rhodesian African Rifles, 1940-45}

The same manpower problems affected Southern Rhodesia at the outbreak of the Second World War; her white population was larger, but could in no way sustain all-white units as had been attempted in the First World War. The Rhodesian African Rifles (RAR) came into existence as a permanent unit in Southern Rhodesia's Defense Force in 1940 amid controversy. Necessity, however, forced

\footnotetext{
${ }^{34}$ Col. Kim Rule, The Rhodesia Native Regiment: A Battle History 1916-1918, Lion \& Tusk, Vol. 5, No. 1, Autumn 1993.

${ }^{35}$ Col. Kim Rule, The Rhodesia Native Regiment: A Battle History 1916-1918, Lion \& Tusk, Vol. 5, No. 1, Autumn 1993.
} 
the pace and dictated the composition of the Southern Rhodesian Army during the War. Up until that point any suggestion of emulating the Northern Rhodesian experience caused an outcry.

The newspapers were filled with letters asserting that the inevitable result of arming and training a large body of Africans would be the extinction of the white man in Rhodesia. They reminded the nation (in lucid and horrifying detail) of the Matabele and Mashona rebellions which had ravaged the country a little more than forty years ago. ${ }^{36}$

Rhodesians from both sides of the Zambezi were reluctant to raise and arm Africans. The RAR never got larger than a battalion in strength during the Second World War, while the NRR rose to eight battalions. This may have been a question of expense as much as anything else, but it is also likely that it reflected Southern Rhodesian fears about armed Africans.

The drain on white manpower meant that objections to raising the RAR were overruled as frivolous or against the war effort. The chief objection came from the farming community which was heavily dependent on African labor. However, since the amount of men needed to form two battalions would take less than two percent of the total available African manpower, the objections were dismissed. ${ }^{37}$

Even the objections of the South African Government which, beyond a few labor units, had an all-white army, were ignored by the Southern Rhodesians, and what appears to have been a new attitude among Rhodesians about armed Africans and the RAR developed:

In fact within a few short months of its inception, an extraordinary surge of feeling for the new regiment began to grip the general public. White Rhodesians took the Battalion to

${ }^{36}$ Owen, The Rhodesian African Rifles, p. 2.

${ }^{37}$ Owen, The Rhodesian African Rifles, pp. 3-4. 
their hearts, and any parade always attracted an enthusiastic audience. It was soon apparent that the regiment was regarded with widespread pride and affection. ${ }^{38}$

Why the turn around in public opinion should have taken place is not easy to explain. Rhodesians and South Africans, or more accurately Afrikaners, had always had a difficult relationship with one another and it may be that acceptance of the RAR by Rhodesians, with their strong pro-British loyalties, was another way of showing it. It is also possible that, after forty years of peace, Rhodesians believed that they had found the formula for peaceful coexistence with the black majority. An article in the Star, a Johannesburg newspaper, while giving an effusive description of Southern Rhodesia's enthusiastic war effort, in contrast to the divided opinion about the war in South Africa, also heaps praise on the Colony's race relations:

This desire to do their utmost to help the Empire and France crush the menace of Nazism is not confined to the European population. It is the desire, also, of the native population to play their part. The loyalty of the native people is unquestioned. The arrival of the British 50 years ago saved them from extermination by internal warfare, periodical famines and disease. During the last 40 years they have lived in peace, their numbers have doubled, they have grown rich in cattle, they live in security and contentment in their reserves, and know that there is always work for them on mines and farms and in the towns to enable them to earn money for their expanding needs. They have every reason to be satisfied with British rule, and they have no desire to change it. The natives will not be used in the fighting forces, but their services as laborers and camp servants will be valuable. ${ }^{39}$

Obviously, the last sentence reflected thinking in the early days of the war but, given this rosy description, which Rhodesians were to

\footnotetext{
${ }^{38}$ Owen, The Rhodesian African Rifles, p. 4.

${ }^{39}$ Article from The Star, 30 November 1939. PRO DO 119/1114
} 
incorporate into the national ideal, the establishment of an African unit was the next logical step. The creed of partnership between the races, never a very-well defined ideal of Cecil Rhodes, found expression after the Second World War in the short-lived Federation of Rhodesia and Nyasaland:

Race relations in the Federal Army were generally v. good indeed. In fact no one ever used the term or thought in "politically correct" terms as is fashionable today. I did not, nor did anyone else think about a native uprising. ${ }^{40}$

The RAR had 'arrived' and the change in attitudes in Southern Rhodesia was vividly illustrated in the 1950 s with the Rhodesia and Nyasaland Army which had, for most of its existence, only four regular infantry battalions, all of whom were classical askari units. ${ }^{41}$

That, however, was for the future. The problem facing the new unit, and for the Government of Southern Rhodesia, was what to do with it. Whether or not this was because the RAR did not come under the authority of the African Colonial Forces, or because of the fears of having Africans askaris exposed to the corrupting influences of the outside world, or whatever, is not known. What is true is that the men who joined were generally eager to go to war so that by 1942 with the prospect of no action in sight, the situation was becoming critical:

On several occasions the Battalion was ordered to prepare for a transfer, and embarkation leave was granted, but each time the

${ }^{40}$ Letter from Colonel Welch dated August 28, 1993.

${ }^{41}$ The Rhodesian African Rifles, the Northern Rhodesia Regiment, and 1st and 2nd (Nyasaland) Battalions of the King's African Rifles. In 1961 two regular, all-white units were added to the Federal Army for the first time; 1st Battalion, the Rhodesian Light Infantry and 'C' Squadron, Rhodesian Special Air Service Regiment. RLI never rose above battalion strength and the SAS was a company-size special force unit. The Southern Rhodesia Artillery Regiment, which had existed since 1948, and the Rhodesian Armored Car Regiment, which was raised and disbanded four times after 1941 , were white reserve battalions. 
men returned to camp they were told that the posting had been canceled. One officer became so frustrated by this continuous wavering that he retired to his bed and refused to leave it for several days. Other officers applied for postings to more active units, and others eased their irritations by turning mess nights into minor riots. As for the askari - they simply downed tools and "went home". Or else they indulged in petty crime. ${ }^{42}$

It was not until 1944, after tasks that included escorting POWs from Durban to Southern Rhodesia and endlessly repetitive training, that the RAR went to war in Burma as part of a backup unit for the 11 th (East African) Division. ${ }^{43}$

The RAR returned to Southern Rhodesia at the end of the war to praise and acceptance by Southern Rhodesia, in stark contrast to the RNR's fate in $1918 .{ }^{44}$ The Regiment was awarded the RNR's battle honors from the First World War and was not disbanded like its predecessor. Until the establishment of the regular white combat units in the early 1960s it was Southern Rhodesia's only regular combat unit. It took part in the Malayan Emergency and was expanded during the Chimurenga War, remaining faithful to the Rhodesian government

\footnotetext{
${ }^{42}$ Owen, The Rhodesian African Rifles, p. 14.
}

43 "It was also the intention that there should be two brigades in reserve from which reinforcements could be drawn in bulk. One of these was the 28th (East African) Brigade...The other, the 22nd (East African) Brigade, consisting of the 1st (Nyasaland) Battalion, King's African Rifles; the 5th (Kenya) Battalion, King's African Rifles; and the 3rd Northern Rhodesia Regiment, arrived in Ceylon from Mombasa in July, 1944.

In August the 5th Battalion, King's African Rifles left the 22nd Brigade to join the 11 th Division. A month later its place in the Brigade was taken by the 1st Battalion, Rhodesian African Rifles, which had completed eight months training in East Africa." J.F. MacDonald, The War History of Southern Rhodesia, 1939-45, Vol. 2, p. 573.

${ }^{44}$ 15,153 Africans joined the Southern Rhodesian Army of whom 1,503 served outside of the Colony. Africans who served in Southern Rhodesia served as guards for the various military installations in units such as the Air Askari Corps. The ones who served overseas went to Burma. J.F. MacDonald, The War History of Southern Rhodesia, 1939-45, Vol. 2, Appendix, p. i. 
until 1980 when it became part of the Zimbabwe National Army. ${ }^{45}$

45 "During 1953 The Rhodesian African Rifles were presented with their Queen's and Regimental Colors by Her Majesty Queen Elizabeth the Queen Mother. Later the Battle Honors of 'Arakan Beaches', 'Taungup' and 'Burma 1944-1945' were added to those ['East Africa 1916-1918'] received by the Rhodesia Native Regiment in World War I" A Brief History of the Rhodesia Army, pp. 13-14. 
THE ALLIANCE; Britain, Southern Rhodesia and the African Colonial Forces, 1935-1945

The coming of the Second World War brought about a more radical change in the organization and mission of Southern Rhodesia's minuscule armed forces than anything that had gone before. From being a part of the BSAP's scheme for internal defense of the Colony, the army became an adjunct to Imperial defense and brought about radical change and expansion. The changes that affected the army came from a need by the British for officers and NCOs for their African colonial units. It altered the entire nature of the army and ultimately its future development.

Until 1931 the military forces in Britain's sub-Saharan African colonies came under two officers; the Inspector-General of the KAR and the Inspector-General of the RWAFF. In September 1931, the two positions were combined into that of Inspector-General of the KAR and the RWAFF; in 1939 the title became the Inspector-General of African Colonial Forces. This semantic change also obviated the need to place the NRR, now well on the way to becoming integrated into the Colonial military system, under the organizational umbrella of either the KAR or the RWAFF. The new position also carried a higher rank and was now to be held by General officers and not Colonels as 
had been the case up to this point. ${ }^{1}$

The Inspector-General could now examine wider strategic questions that would concern the employment and disposition of all African forces, beyond the more parochial ones that would have existed before. As with any administrative innovations undertaken during this period, there was a persistent shortage of funds and, therefore, manpower.

Brigadier C.C. Norman, the first Inspector-General of the KAR and the RWAFF (1931-1936), was primarily concerned with saving money for the financially hard-pressed British Government in the middle of the world Depression. ${ }^{2} \mathrm{He}$ and a Royal Air Force (RAF) officer, Air Vice-Marshal C.L.N. Newall, recommended drastic changes to the force structure in east and central Africa in order to save money and take advantage of the technology, "...of modern aircraft development."

The Newall-Norman Report began by reviewing the existing situation. Conditions were quiet, but the civil police had been reduced to a minimum and had no reserves. The Report recommended, therefore, that the police should have the assistance not only of the KAR, but of an organized air arm and local defense force. The nomadic tribes in British territory along the Abyssinian border had now been disarmed, but were still subject to sporadic raids, which military garrisons were too scattered and weak to prevent. The Report recommended that for this purpose aircraft should be used in conjunction with police, and the military forces withdrawn. ${ }^{3}$

The proposed cuts would have reduced the strength of the $820 / 25 / 12$.

${ }^{2}$ Lt. Col. H. Moyse-Bartlett, The King's African Rifles, p. 464.

${ }^{3}$ Lt. Col. H. Moyse-Bartlett, The King's African Rifles, p. 466. 
forces in east and central Africa from seven battalions (six KAR and one NRR) to four with a squadron of aircraft to make up for the lost ground forces in this early version of a rapid deployment force. The argument could be seen as an analogy to the merits of the policeman on the beat against the policeman in a patrol car. The size and numbers of the KAR battalions, and the size of the NRR were very small anyway, and the number of British officers available for them even smaller so that Royal Marine officers had to be seconded. ${ }^{4}$

The Newall-Norman Report, overtaken by events, was never implemented to the relief of the soldiers and others familiar with Africa who were skeptical of the idea of askaris being flown to hot spots instead of patrolling them. The ideas expressed were not altogether unpopular with settlers and the administrations in the territories to the north of Southern Rhodesia where defense costs were mandated by London, but paid for out of local revenues, "It was not easy to persuade the governments of the colonial territories to accept a comprehensive view. The whole history of their military affairs is one of violent fluctuations between drastic economy and hasty rearmament."

In 1936 Major-General G.J. Giffard became Inspector-General of African Colonial Forces and in 1937 made his first tour of the African Colonial Forces. This was also the year that saw the beginning of the reorganization of the NRR, separating it completely from its police past so that it became a regular colonial infantry battalion. Beyond this

\footnotetext{
${ }^{4}$ James Lunt, Imperial Sunset, p. 220.

5 James Lunt, Imperial Sunset, pp. 205-206.
} 
administrative reform in his bailiwick, Major-General Giffard's chief concern was the Italian invasion of Ethiopia which "...brought home to the Colonial Governments and their Legislatures that there was a threat and that it was not far from their borders."

The Italo-Abyssinian war threw the northern frontier of Kenya into a turmoil. As the Italian armies swept across the country, refugees with their herds of stock, armed bandits and deserters came pouring into the Northern Frontier District. Troops had to be called upon to support the police; 3 KAR (relieved later by 5 KAR) were at Meru and forward detachments were again established at Wajir, Mandera, Moyale, and Malka Murri. Meanwhile, as similar disturbances were expected on the frontiers of British Somaliland...

Giffard's strategic problems were peripherally complicated by the Third Reich's intrusion in African affairs in the form of "Hitler's extravagant demands for the return of the former German colonies [which] were not without their effect on the German settlers in Tanganyika." ${ }^{8}$ This was a demand that was soon dropped as Hitler's territorial ambitions were entirely directed towards Europe. It did have the effect of scaring South Africa and Britain. From the point of view of the professional infantry soldier, things were looking up.

However, the years between the two world wars had not been kind to the British Army; the problem was not in finding enough Africans to join the KAR, NRR or the RWAFF, which had always been manned by volunteers, but finding enough qualified officers and senior NCOs to lead them. There was no question in the eyes of the planners

\footnotetext{
${ }^{6}$ James Lunt, Imperial Sunset, p. 220.

${ }^{7}$ Lt. Col. H. Moyse-Bartlett, The King's African Rifles, p. 467.

${ }^{8}$ Lt. Col. H. Moyse-Bartlett, The King's African Rifles, p. 467.
} 
that the best people to do this were whites who were familiar with Africans and their ways.

Part of the solution was to create Territorial, or reserve, units for settlers like the Kenya Regiment (KR) which was raised in $1937 .^{9}$ The function of the KR was to act as a leader's training unit, to assist the Kenya Defense Force and provide reservists for the internal security of the Colony. ${ }^{10}$ In Northern Rhodesia, the newly created NRR had its own Reserve of Officers. ${ }^{11}$ However, it was realized that the Kenyan settlers could not supply the complete manpower needs visualized by Giffard.

The British Government, and Giffard, approached the Government of Southern Rhodesia to find the additional leadership for the colonial forces that would be needed when and if a general war broke out. As an example of cooperation between two governments, it was probably one of the best in the British Empire and resulted in a policy that expanded and changed the role of the Rhodesia Regiment.

...it was decided to reorganize the Forces so that the Defense Force should not only be prepared for internal security, but also take part in action overseas. Each battalion of the Rhodesia Regiment was reformed into two groups so as to be able to carry out their new roles. The Permanent Staff Corps was increased to 22 officers and 25 other ranks to assist in the specialist training necessary. ${ }^{12}$

\footnotetext{
9 "In all over 3,500 members of the Regiment joined the East African Forces. Of these more than 1,500 were commissioned as officers in the battalions of the King's African Rifles from Kenya, Uganda, Tanganyika and Nyasaland, and in the Northern Rhodesia Regiment." Campbell, The Charging Buffalo, p. 27. 17.

${ }^{10}$ Sir Guy Campbell, The Charging Buffalo, A History of the Kenya Regiment, p.

${ }^{11}$ W.V. Brelsford, The Story of the Northern Rhodesia Regiment, pp. 73-74.

${ }^{12}$ A Brief History of the Rhodesia Army, p. 9.
} 
General Giffard put forward recommendations which completely changed the Rhodesia Regiment as a unit. Hitherto the regiment had been nothing more than two under-strength reserve battalions of infantry, but it was now to become a leaders' training unit, like the KR, that supplied officers, NCOs and other specialists, not only to be dispersed around the British Army, but primarily to the African Colonial Forces. ${ }^{13}$ The leadership needs of the NRR expanded as the Regiment grew from one to eight battalions during the Second World War. ${ }^{14}$ The KAR's expansion was just as spectacular. ${ }^{15}$

In 1938 the Southern Rhodesian Defense Force, which included the Colony's Air Unit, numbered nine Permanent Staff Corps officers and forty-five 'Other Ranks', or enlisted personnel, who served as instructors. The two battalions of the Rhodesia Regiment, when fully mobilized, numbered around 600 men “....and the compulsory system of registration for military service has built up a considerable reserve

${ }^{13}$ "The Rhodesian contingent arrived in November 1939 in all [west African] colonies to bring existing forces up to establishment. They were all Rhodesian territorials and knew very little militarily; but they did know a lot about Africans. They made a tremendous contribution to the RWAFF..." Lunt, Imperial Sunset, pp. 195196.

${ }^{14} 1$ NRR fought at the Battle of Tug Argan, British Somaliland (August 1940) but not in the Abyssinian campaign of 1940-41. 1 NRR later served in Burma with the 11 th (East African) Division, in 1944-45. 3 NRR served in Burma in the 22nd (East African) Brigade. The other battalions of the NRR served out the war doing garrison duty in Palestine, Ethiopia, Madagascar, and Somalia. Lunt, Imperial Sunset, p. 303.

15 "By VJ day the original six battalions [of the KAR ] had expanded to fortythree; there were also six independent garrison companies and three Division Headquarters Protection Companies. '...the maximum war effort ever achieved as a whole was the provision and maintenance of a complete division plus two brigades in Burma during the operations of $1944-45$, at a time when the internal security of vast territories on the [African] Continent and in Madagascar had also to be safeguarded."' Lunt, Imperial Sunset, p. 223. 
behind them." ${ }^{16}$ The BSAP consisted of twenty-three Officers and 463 Other Ranks. While not an overwhelming number of men, it was large by the standards of a relatively small African territory, and did not escape the notice of the Committee of Imperial Defense-Oversea Defense Committee (CID-ODC) in London, whom Southern Rhodesia dealt with on mutual defense matters.

Southern Rhodesia, perhaps more than any of the other colonies or dominions, enjoyed a very close emotional relationship with the mother country. Whether it was because they were not ruled from London, which probably gave Rhodesians a kinder view of Britain, a view not always shared by settlers in Kenya and Northern Rhodesia, or because of the residual of ill-feeling between Rhodesians, as 'Englishmen', and the Afrikaner-dominated Union of South Africa, or the large number of British ex-servicemen in Southern Rhodesia, is outside of the scope of this study. The fact is that they took pride in being an active part of the British Empire. An indication of this, according to CID-ODC, was Southern Rhodesia's willingness to give their all, seemingly without any reservations:

Should the British Empire be involved in war, Southern Rhodesia would be ready and eager to place such of her forces as could be spared at the disposal of the United Kingdom Government for service where most required. ${ }^{17}$

While this sentiment was being expressed, the practical needs of the British Government in the face of the rising threat from Italy and Germany, was beginning to conflict with Southern Rhodesia's

\footnotetext{
${ }^{16}$ ODC Minute No. 305,1938, p. 2. PRO CAB $10 / 9$.

${ }^{17}$ ODC Minute No. 305, 1938, p. 2. PRO CAB 10/9.
} 
objection to having African soldiers. The practical solution of having armed Africans to fight in the War would win out, given the small number of whites on both sides of the Zambezi, but until that time the British Government deferred to Rhodesian sensibilities. Under the heading "Internal Security" a CID-ODC document in 1938 stated:

Southern Rhodesia is preponderantly an area for white settlement, and the African population, which is relatively small compared with that in Northern Rhodesia and Nyasaland, is mainly concentrated in the reserves.

The B.S.A. police, supported in time of emergency by the Southern Rhodesia Defense Force, (two battalions of European Territorial infantry recruited on a compulsory basis), provide an adequate force for the maintenance of internal security. A situation calling for assistance by African troops from Northern Rhodesia or Nyasaland to maintain or restore order in Southern Rhodesia is unlikely to arise. Moreover, the Committee understand that the Government of Southern Rhodesia would not agree to the employment of African troops, since they are opposed to the placing of arms in the hands of Africans. The maintenance of internal security in this Colony may therefore be considered adequately provided for under the existing organization. ${ }^{18}$

In the same document the CID-ODC outlined the tactical and strategic problems facing the British colonies in east Africa and the forces available to defend them in the face of possible Italian aggression.

Italy has announced publicly the strength of the permanent garrison which she intends to maintain in Italian East Africa, including Abyssinia, and this far exceeds the forces which the British Dependencies on her borders can maintain in time of peace.

...Although the scale of attack may not, for various reasons, be as heavy as first sight might appear likely, it would probably be heavier than the forces immediately available in Kenya, Uganda and Somaliland could withstand without assistance.

... arrangements have been made for the co-operation of all the forces in Central and East Africa to meet the contingency of

${ }^{18}$ ODC Minute No. 300, 1938, pp. 1-2. PRO CAB 10/9. 
Italian attack. All the local forces are being organized, equipped and armed on identical lines to facilitate this co-operation. ${ }^{19}$

Having outlined the situation, it went on to outline the problems which faced them, especially as it concerned the issue of white versus black soldiers.

It will be convenient here to point out that the last war in East Africa showed that only units composed of Africans with white leaders were suitable for service in tropical Africa... It was not possible to maintain European and Indian units in a proper state of health.

The defense of the British African territories, which lie mainly in the tropical belt, must, therefore, be maintained by African units. ${ }^{20}$

The process of transformation in Southern Rhodesia's defense establishment was such that by December 1941 the process of turning the two battalions of the Rhodesia Regiment into a training unit like the Kenya Regiment, was completed. The 3rd and 4th Battalions were raised, trained, and disbanded to form the training, or Depot Companies, of the 1st and 2nd Battalions. ${ }^{21}$ Southern Rhodesia produced enough men so that by the end of the war around 10,000 white Rhodesians served in the British forces which were ultimately drawn from Southern Rhodesia's white population of $67,000 .^{22}$

\footnotetext{
${ }^{19}$ ODC Minute No. 300,1938 , pp. 4-5. PRO CAB 10/9.

${ }^{20}$ ODC Minute No. 300,1938 , p. 5. PRO CAB 10/9.

${ }^{21}$ A Brief History of the Rhodesia Army, p. 10.

${ }^{22}$ Total white males were 9,187 of whom 6,520 served outside of Southern
} Rhodesia. Total white females were 1,510 of whom 137 served outside of Southern Rhodesia. There were 271 Colored males of whom 228 served outside of Southern Rhodesia and 15,153 male Africans of whom 1,503 who served outside of the Colony. Of this total, eight were killed in action, either in the Royal Navy or the South African Navy, 407 were KIA in the Army and 498 in the RAF. Three women were killed. J.F. MacDonald, The War History of Southern Rhodesia, 1939-45, Vol. 2, Appendix, p. i. 
CHAPTER VIII

\section{WHITE RHODESIAN UNITS IN THE SECOND WORLD WAR}

While the Southern Rhodesian War Diary is full of endless examples of the dispersion of Rhodesians throughout the British Army, there were only two all-white Rhodesian fighting units formed in Southern Rhodesia during the war, although there were others formed in various theaters where Rhodesians were concentrated. ${ }^{1}$

Giffard's recommendations for the reorganization of Southern Rhodesia's defense establishment, called for “...a mechanized [artillery] battery and an armored fighting vehicle unit, which would absorb personnel not required, or unsuitable, for training as European leaders for native units." The CID-ODC recommended that the Southern Rhodesians form a reconnaissance unit of trucks in lieu of receiving armored vehicles, which would "...in all circumstances, be more appropriate to the resources and condition of service in

\footnotetext{
"13.4.40 Southern Rhodesian contingent for Middle East and United Kingdom. 32 Officers, 11 WOs, 134 NCOs, 579 ORs left for embarkation at Durban on the 16th en route for Egypt." In this group one complete mechanized artillery battery and one mechanized Reconnaissance unit were sent. There were Engineers, Signalers, machine gunners, five companies of infantry (to be distributed amongst nine British infantry regiments), and various staff officers. On the 25 th December 1939, the War Diary records that there were Rhodesian Officers and NCOs in Iraq, British Somaliland, Nigeria, Gold Coast, Gambia, Sierra Leone, Kenya and Tanganyika. PRO WO 333/1.

${ }^{2}$ ODC Minute No. 305, Cooperation of Southern Rhodesia in Imperial Defense, 1938, p. 3. PRO CAB 10/9.
} 
Southern Rhodesia."

However, this was for the future and the plans that would bring about these changes did not come into full focus until the outbreak of war fourteen months later. The CID-ODC, while primarily interested in bringing the African Colonial Forces up to strength in white officers and NCOs, recognized the fact that not Rhodesians were of the right stuff to lead African soldiers. The CID-ODC supported the idea of dispersing them throughout the British Army:

The Committee, however, fully agree with the view of the Inspector-General that it would be wasteful to employ European infantry as reinforcements in other parts of Africa where climactic conditions are unsuitable for their use. Other and better employment could be found for this valuable material from Southern Rhodesia. ${ }^{4}$

The first all-white Rhodesian units made their appearances in the 1940 Report on Defense. As mentioned above, these units would survive, to be disbanded and reformed, in one form or another by a later Rhodesian Army.

Full-Time units within the Colony.

1. Southern Rhodesia Reconnaissance Unit.

After the departure of the drafts to the Middle East in April, this unit was left without personnel with the exception of two officers lent to the colony from the [British] Regular Army. Some time elapsed before this deficiency could be made good, due in part to the fact that the camp set aside for this unit at Umtali was not ready for occupation. The buildings, however, were pushed on with great speed, and by the end of the year the unit had, to a great extent, been reorganized, trained and equipped.

\footnotetext{
${ }^{3}$ ODC Minute No. 305 , Cooperation of Southern Rhodesia in Imperial Defense, 1938, p. 5. PRO CAB 10/9.

${ }^{4}$ ODC Minute No. 305, Cooperation of Southern Rhodesia in Imperial Defense, 1938, p. 3. PRO CAB 10/9.
} 
2. Light Battery.

Personnel for this unit was provided and trained in a similar manner, but during the year the nucleus, followed by drafts, was required for the S.R. Anti-Tank Battery in East Africa, and consequently the end of the year found the Light Battery for the most part in training with new personnel for the third time.

3. Southern Rhodesia Medical Corps.

This unit carried on its training as a Depot, and when accommodation was ready it was quartered in King George VI Barracks. Apart from the general depot training and the provision of trained personnel for the Base Hospital in East Africa and the Rhodesia Air Training Group, the unit proceeded to form a motorized Field Ambulance, which in 1941, when accommodation is ready, will be stationed in Umtali with the Recce Unit.

\section{Signal Company.}

The Training of this unit, which is to produce signalers to the standard of the Royal Corps of Signals, has proceeded steadily. Whilst providing drafts of signalers for duty outside the colony, it is also producing and will shortly have ready, signalers who will operate on a mechanized basis with S.R. Recce Unit.

\section{General.}

In addition to the general training and drafting activities of all full-time units, when combined, they form within the Colony a mechanized striking force. ${ }^{5}$

In February 1941, some Rhodesians were withdrawn from

British units in Egypt. ${ }^{6}$ They were transferred to Kenya where the Southern Rhodesia Armored Car Regiment was being formed as an allRhodesian unit as the British offensive was getting under way in

\footnotetext{
${ }^{5}$ J.F. MacDonald, The War History of Southern Rhodesia, 1939-45, Vol. 1, p. 131.

${ }^{6}$ They came from the 11 th Hussars, the Royal Northumberland Fusiliers, the Durham Light Infantry, the Buffs (Royal West Kent Regiment), the Sherwood Foresters, the Leicestershire Regiment, and the Argyle \& Sutherland Highlanders. MacDonald, War History, Vol. 1, p. 155.
} 
Ethiopia, “...an offensive in which, to their disgust, the Rhodesian Armored Cars could not take part."

The regiment's job for almost the next two years consisted of garrison duty in the occupied Italian territories of East Africa. They assisted in the evacuation of prisoners and civilians, doing convoy protection, reconnaissance work and, because they were split into their sub units, were dispersed over northern Kenya, Sudan, Abyssinia and Eritrea. ${ }^{8}$

They were the first Southern Rhodesian unit to be affected by the decision to unify the command of Southern Rhodesia's forces with South Africa's Union Defense Force on the 22nd October 1942. They drove back to Southern Rhodesia where they were told by R.C. Tredgold MP, Southern Rhodesia's Minister of Defense, that they would be absorbed into the South African Army as a Rhodesian unit. ${ }^{9}$ In November 1942, the regiment, 550 strong, moved to the South African province of Natal where they drew South African uniforms and, in January 1943, embarked at Durban for Egypt where they joined the South African forces. They eventually received tanks and served in the Italian campaign. ${ }^{10}$

The next area of expertise which Rhodesians acquired was in

${ }^{7}$ J.F. MacDonald, The War History of Southern Rhodesia, 1939-45, Vol. 1, p. 155.

${ }^{8}$ J.F. MacDonald, The War History of Southern Rhodesia, 1939-45, Vol. 1, pp. 253-254.

${ }^{9}$ J.F. MacDonald, The War History of Southern Rhodesia, 1939-45, Vol. 2, pp. 372-373.

${ }^{10}$ They were divided up into three Squadrons and went to the Pretoria Regiment (Princess Alice's Own), Prince Alfred's Guard and the Special Service Battalion (Permanent Force Regiment), all part of the 12th (South African) Armored Brigade, 6th (South African) Armored Division. MacDonald, The War History, Vol. 2, p. 398. 
artillery which "...owing to the heavy demand at the present time on the armament industry of the United Kingdom, some time must inevitably elapse before 3.7" Howitzers for a mechanized battery and vehicles for an armored fighting vehicles could be made available..." As they were to form part of the British Army, the cost for equipping, instructing and supporting the units and men involved, would ultimately fall on the British Government.

The War Diary for the 27th of September 1940, the 4th (Rhodesian) Anti-Tank Battery, consisting of a skeleton crew of one officer and eighteen other ranks left for Nairobi to prepare for the formation of the unit which would be provided with drafts from the training units of Southern Rhodesia. ${ }^{12}$ They were formed into the 4 th (Southern Rhodesia) Anti-Tank Battery, which was brought up to strength by drafts from Southern Rhodesia, equipped with twopounders, and joined the 12th (African) Division at the end of $1940 . .^{13}$ In April 1940, Rhodesian signalers went to the British 7th Armored Division, 'the Desert Rats. ${ }^{14}$ In May 1941 the Anti-Tank Battery was sent to Egypt and by September was incorporated into a British

\footnotetext{
${ }^{11}$ ODC Minute No. 305, Cooperation of Southern Rhodesia in Imperial Defense, 1938, p. 4. PRO CAB 10/9. 130.

${ }^{12}$ J.F. MacDonald, The War History of Southern Rhodesia, 1939-45, Vol. 1, p.

${ }^{13}$ J.F. MacDonald, The War History of Southern Rhodesia, 1939-45, Vol. 1, p. 157.

${ }^{14}$ They formed ' $\mathrm{H}$ ' Troop of the 3rd Royal Horse Artillery, the division's only anti-tank regiment, and ' $R$ ' Troop of the division's Support Group. MacDonald, War History, Vol. 1, p. 54.
} 
artillery regiment. ${ }^{15}$

In May 1940 the Medical Corps supplied the staff to form 'No. 2 General Hospital (Southern Rhodesia)' in Nairobi. Like the other Rhodesian contributions to the war effort, it became a considerable investment of manpower, presumably in anticipation of expected casualties of the Ethiopian campaign, “...it had been expected that General Cunningham's offensive would fill the wards, but although few beds in the great three story building were empty, yet not many of the patients were actual battle casualties." ${ }^{16}$ There were around two hundred and fifty Rhodesian officers and a thousand other ranks manning the hospital who were eventually relieved and posted elsewhere in July, 1943 when the hospital was taken over by the British. ${ }^{17}$ Many of the Rhodesians would eventually end up in India and Burma. $^{18}$

Another excellent example of the ongoing willingness of the Southern Rhodesian government to cooperate with the manpower wishes of the British Army was the number of Rhodesians who served in two of the most famous special force units to come out of the Second World War; the Long Range Desert Group (LRDG) and the Special Air Service (SAS), both of which were formed in Egypt in

\footnotetext{
${ }^{15}$ The 102nd Anti-Tank Regiment, Northumberland Hussars. MacDonald, War History, Vol. 1, p. 276.

${ }^{16}$ J.F. MacDonald, The War History of Southern Rhodesia, 1939-45, Vol. 1, pp. 167-168.

${ }^{17}$ J.F. MacDonald, The War History of Southern Rhodesia, 1939-45, Vol. 1, pp. 252-253. 420.

${ }^{18}$ J.F. MacDonald, The War History of Southern Rhodesia, 1939-45, Vol. 2, p.
} 
1940 and 1941 respectively. Because Southern Rhodesia had no large national formations there was no political pressure, as was the case with the New Zealanders and the LRDG, that prevented small groups of Rhodesians from volunteering and serving with both units for the duration of the war:

...the fears of their Government at home about keeping the [New Zealand] Division up to strength that had prompted them to consider removing our Squadron. I also said that, unless we could get a guarantee of continued maintenance of the $\mathrm{NZ}$ Squadron up to establishment, we would be far wiser to let them go. In that case we should try to get a Rhodesian Squadron if we could. ${ }^{19}$

By way of contrast, the Government of Southern Rhodesia was more than happy to have the LRDG make use of their men:

It was a stroke of good luck which brought Sir Ernest Lucas Guest, the Rhodesian Air Minister, on a visit to the Middle East at that time. During his tour he came to see our Rhodesian contingent. He was full of understanding, and I took to him. I did all I could to persuade him that in future the LRDG ought to have a Squadron of Rhodesians. I could think of no better substitute for the men from New Zealand. ${ }^{20}$

As it happened, the formation of the Rhodesian squadron in the LRDG coincided with the move to establish Rhodesian subunits in the 6th (South African) Armored Division which was being formed in South Africa at around the same time. A serving Rhodesian officer from the LRDG went to Southern Rhodesia on a recruiting drive, and after a special training course, “...under an agreement reached between Commander-in-Chief, S.A. Command and the Commander

\footnotetext{
${ }^{19}$ Maj. Gen. D.L. Lloyd-Owen, Providence Their Guide, p. 151.

${ }^{20}$ Maj. Gen. D.L. Lloyd-Owen, Providence Their Guide, p. 151.
} 
Military Forces, the men selected proceeded to the Middle East."21

The LRDG led the Rhodesians into contact with the SAS which was being shuttled across the desert by them until they were able to organize their own transportation. The man who was responsible for reintroducing Southern Rhodesia to the SAS after the war was Major J.M. Calvert. He was presumably so impressed with the caliber of the Rhodesians he had served with, that he was determined to have them take part in the Malayan Emergency in the 1950s as an integral part of the SAS which was being reformed in the British Army. ${ }^{22}$ Rhodesians were thus kept abreast of military developments, and were thought highly enough of, to be included in British Army plans for the future. The tradition of innovation from below and links with the British were strengthened by the war.

\footnotetext{
${ }^{21}$ Southern Rhodesia Annual Report on Defense for 1943, p. 73. Annual Report on Defense for 1939-45. British Library (CS. D.)

22 'A' Squadron, 22 SAS was formed from British Army volunteers in Malaya, 'B' Squadron was formed from volunteers from the reserve unit, 21 SAS Regiment (Artists) (V), which had taken over the title and battle honors of the Artist Rifles, a London regiment. The Rhodesian Far East Volunteer Unit became 'C' Squadron and was commanded by Major Peter Walls, the future COMOPs commander. When it was added to the Rhodesian Army in 1962, it was known as 'C' Squadron, Rhodesian SAS Regiment. To this day 22 SAS does not have a 'C' Squadron. James Shortt, The Special Air Service, pp. 18-19.
} 


\section{CHAPTER IX}

THE QUEST FOR AIR POWER;

the Rhodesian Air Force, 1934-1945

The quest for Rhodesian air power began in 1934 when members of the Southern Rhodesian parliament expressed a desire to contribute something towards the defense of the British Empire. The Rhodesian parliamentary debate, reported in the Rhodesia Herald and included as part of a report to the Council for Imperial Defense, indicates the number of former military men present in Southern Rhodesia. The expression, 'Officers to Kenya, Sergeants to Rhodesia' is more indicative of the social standing of Kenya's settlers than anything else, but the fact that both colonies' were the destination of so many former soldiers is significant. Kenya and Southern Rhodesia had long attracted former soldiers for a variety of reasons, and the end of the First World War saw a large influx of them into both colonies. Kenya had the reputation of attracting upper class settlers, one of the few in the British Empire to do so, while in Rhodesia the social tone was set a little lower. It meant that there was already a significant body of men with military experience. In the case of Kenya, a tour of duty with the KAR occasionally caused a seconded officer to resign his commission and settle there.

In any case, it was from a genuine, albeit quaintly expressed, desire to help Britain and the Empire during the depth of the 
Depression, that heralded the beginnings of the Rhodesian Air Force.

The parliamentary debate of April 1934 came up with an offer to donate $£ 10,000$ from the tax revenues of Southern Rhodesia to the Royal Navy. The thinking was that this sum, the interest on which could pay for one light cruiser, would be a "debt of honor" more than anything else, a gesture by Rhodesians to a force that was doing so much to keep the sea lanes open and preserve peace. While the voices in the House were raised in favor of the Navy, there were also those who, while they were willing to give the money to the Royal Navy, brought up the possibility of a local air defense unit of some kind.

Colonel T. Nangle (Salisbury District, Reform Party) supported the principle of the motion, but moved an amendment to make the motion wider so that it would include the Air Force. He asked that the Prime Minister should get in touch with the Imperial Defense Committee and consult with them as to the allocation of the money. Colonial-born boys, he said, took to the air and during the war 80 percent of the flying men [in the Royal Flying Corps] were Colonial born. ${ }^{1}$

The Prime Minister of Southern Rhodesia, Godfrey Huggins visited London that year and met the CID-ODC in order to discuss mutual defense issues. ${ }^{2}$ He was told by Lord Hailsham, Secretary of State for War, that the sum would be far better spent on developing

\footnotetext{
${ }^{1}$ Extract from Press Report from the Rhodesia Herald, Thursday April 26th, 1934 , as sent as an enclosure to the Imperial Defense Committee. PRO CAB 16/117.

${ }^{2}$ Dr. Godfrey M. Huggins was the fourth Prime Minister of Southern Rhodesia and the first Prime Minister of the Federation of Rhodesia \& Nyasaland. He was knighted in 1945, and was created Viscount Malvern in 1955. From 1923 until the end of white rule in 1979 there were eight Prime Ministers of Southern Rhodesia: Sir Charles Coghlan (1923-27), Herbert Moffat (1927-33), George Mitchell (1933), Godfrey Huggins (1933-53), R.S. Garfield Todd (1953-58), Sir Edgar Whitehead (1958-63), Winston Field (1963-64), and Ian Douglas Smith (1964-79). The title of Premier was used until 1933 when, after the Imperial Conference in Ottawa, the heads of government of Dominions and Self-Governing Colonies were to be known as Prime Ministers. For simplicity's sake, the latter title will be used throughout. Breslsford, The Handbook of Rhodesia and Nyasaland, pp. 774-779.
} 
Rhodesia's human military potential:

It was necessary that the Territorial Force should be as efficient as possible, and he hoped nothing would be done to detract from the military training of that force. The type of man in it was eminently suited for military purposes... ${ }^{3}$

Presumably having it swallowed up in the vast budget of the Royal Navy, quite apart from the fact that Southern Rhodesia has no coast line, was seen as misusing the best part of Southern Rhodesia's slim resources, which consisted of a reasonably well educated community, many of whom lived on the 'frontier'. The Air Minister spoke for air power:

Lord LONDONDERRY suggested that whereas a part of the sum would be of little practical value to the Navy, yet with $£ 10,000$ it was possible to start the nucleus of a local Air Force which would be of real value. ${ }^{4}$

From a purely political point of view, Huggins “...doubted whether local opinion would be fully satisfied if the sum were merely paid out as a contribution to Imperial Defense with no visible result in the Colony."

The subject of the Southern Rhodesia's small Defense Force came up again, not only from Lord Hailsham and Lord Londonderry's Air Ministry who offered the Southern Rhodesian Prime Minister "...to give all possible help on whatever scheme were to be adopted. If it was decided to start a small air unit in Southern Rhodesia, a nucleus of

\footnotetext{
16/117.

${ }^{3}$ Minutes of Imperial Defense Committee meeting, 31 July 1934. PRO CAB

${ }^{4}$ Minutes of Imperial Defense Committee meeting, 31 July 1934. PRO CAB
} 16/117.

${ }^{5}$ Minutes of Imperial Defense Committee meeting, 31 July 1934. PRO CAB 16/117. 
whole time personnel would be required and a small number of seconded officers from the RAF could be made available."

Prime Minister Huggins' reaction was to repeat the Rhodesian view to the CID-ODC that "...the Territorial Force was intended to serve primarily for their own protection. It was regarded as a local Defense Force rather than as an Imperial Force, although, of course, its personnel might be available for Imperial purposes if the need arose." Because of the unstable world economic situation, Southern Rhodesia was also cutting back on defense expenditure, which meant cutting back on numbers of men and training in the already small Defense Force "...apart from that he did not think that the efficiency of the force had suffered in any way as the economies had largely been effected by a reduction of surplus personnel."

The main question on which he wished advice was whether the sum of $\$ 10,000$ should be handed over as a gift to the Treasury, to be spent on Imperial Defense as a whole, or whether it would be more usefully employed by the establishment of a Territorial Flying unit. ${ }^{9}$

The lack of a wider strategic vision is clearly shown in Huggins' statement, although it is obvious that his instincts were correct. His concerns were picked up by the Army Commander, Field Marshal Sir Archibald Montgomery-Massingberd and he, Huggins, was reassured $16 / 117$.

${ }^{6}$ Minutes of Imperial Defense Committee meeting, 31 July 1934. PRO CAB $16 / 117$. $16 / 117$.

${ }^{7}$ Minutes of Imperial Defense Committee meeting, 31 July 1934. PRO CAB

${ }^{8}$ Minutes of Imperial Defense Committee meeting, 31 July 1934. PRO CAB $16 / 117$.

${ }^{9}$ Minutes of Imperial Defense Committee meeting, 31 July 1934. PRO CAB 
that Southern Rhodesia was important to any future British war effort:

-

Sir Archibald MONTGOMERY-MASSINGBERD said that the War Office regarded the Territorial Force in Southern Rhodesia as a most valuable potential reserve of officers; from that point of view the force had not merely local significance but was an Imperial Asset. ${ }^{10}$

The British Air Ministry and the Secretary of State for War, after a half-hearted attempt by the Navy to get the $£ 10,000$, proposed setting up a 'Southern Rhodesia Air Unit' (SRAU) of minuscule size, to be paid for by the Southern Rhodesian Government. The SRAU would not only spend the money in question on itself, but the unit would eventually contribute to the Colony's defense establishment. The RAF would benefit, as they would be able to use the personnel trained under the scheme, and be able to send their own officers and NCOs to Southern Rhodesia and thus spread their costs. The RAF were suffering from the same financial restrictions as the Rhodesians.

It is proposed to have an annual intake of six candidates who volunteer for training in flying duties on a Territorial basis. They will be required to undertake to serve for a period of five years on the active list and five years on the reserve. It is estimated that the course of training will take two years and that the RAF standard will be adhered to.

From the above it is hoped to gradually build up a reserve of pilots who have been fully trained. To attain this a Flight Lieutenant and a Flight Officer holding CFS and other qualifications will be required to be seconded from the RAF to . the Permanent Staff Corps (Air Section) for a period of three years as instructors. ${ }^{11}$

In 1936 the Government began the air training scheme at $16 / 117$.

${ }^{10}$ Minutes of Imperial Defense Committee meeting, 31 July 1934. PRO CAB

${ }^{11}$ Letter from Sir H.J. Stanley to the Secretary of State for Dominion Affairs, No. 339, Confidential, 10th July 1936. PRO CAB $21 / 642$. 
Cranborne, on the outskirts of Salisbury, and flight training was conducted by the local civilian flying school; flight training was also begun in Bulawayo. In August 1937, seconded RAF personnel began their training program and the "...new service expanded rapidly, as it made a strong appeal to Rhodesian youth."12

Training in elementary flying was carried out on that most dependable of aircraft, the De Havilland Tiger Moth. ...From $T$ iger Moths the young Rhodesian graduated to more advanced flying in Hawker Harts, which even in 1939 were regarded as a trifle antiquated. ${ }^{13}$

In 1936 Group Captain A.T. Harris visited Southern Rhodesia at the invitation of Prime Minister Huggins. Harris recommended that the SRAU...

...should be established by following the gradual introduction of a number of formative stages, each one designed to build and expand on the strength of the previous stage. Following the establishment of a nucleus staff there would be a provision for the training of skilled technical personnel so that the "SRAU" could itself become self-perpetuating in the production of skilled personnel. ${ }^{14}$

The establishment of the SRAU eventually fit very smoothly into British plans, both strategic and political. In July 1939, during another visit to the United Kingdom, Huggins heard that the British wanted to establish a full blown-training program for the RAF. Not only would distance from Europe assure that flight training could proceed safely, but the proximity of South Africa "...would encourage a number of

\footnotetext{
${ }^{12}$ J.F. MacDonald, The War History of Southern Rhodesia, 1939-45, Vol. 1, p. 13.

${ }^{13}$ J.F. MacDonald, The War History of Southern Rhodesia, 1939-45, Vol. 1, p. 13.

${ }^{14}$ Hugh Morgan, By the Seat of Your Pants, p. 11.
} 
recruits to cross the border." ${ }^{15}$ Britain's relationship with the Union of South Africa, as we shall see, was not a happy one in the years leading up to the War.

Within three weeks of the outbreak of the Second World War, five hundred men joined the Southern Rhodesian Air Force (SRAF) which consisted of No. 1 (Cadre) Squadron at the Flying School at Cranborne. It only had of thirteen aircraft, twenty-one staff personnel and fifty men under instruction. The War Diary of Southern Rhodesia recorded that:

Southern Rhodesia Air Force: Survey of information received from recruiting campaign indicates the ability to produce personnel to man three squadrons and a flying training school. Offer made in these terms to Imperial Government accepted. ${ }^{16}$

The RAF was far more prepared, doctrinally at least, to face the Luftwaffe than was normally realized. In the area of Close-Air Support the Germans had an edge, but as far as aircraft design and organization it can be argued that the RAF had the lead. The short explanation is that the RAF, unencumbered by history or debilitating traditions, was able to organize itself to meet the challenge of a future war. Part of the RAF's preparation came in the form of the Empire Air Training Plan (EATP). By way of contrast, the Luftwaffe, as a creation of the Third Reich, became the political bailiwick of Hermann Göring and suffered

\footnotetext{
${ }^{15}$ Hugh Morgan, By the Seat of Your Pants, p. 11.

${ }^{16}$ J.F. MacDonald, The War History of Southern Rhodesia, 1939-45, Vol. 1, p. 32.
} 
as a consequence. ${ }^{17}$

The EATP was originally conceived of in a 1936 memorandum by Group Captain Robert Leckie, a Canadian who had opted to remain with the RAF after the First World War. This document, written with Canada in mind, was seen by Leckie's superior officer, Group Captain Arthur Tedder, later to become Marshal of the RAF during the war. The advantages of having Canada as a training ground for RAF personnel included its relative proximity to the United Kingdom and especially to the United States with its large industrial base. ${ }^{18}$ This also meant that RAF pilots and crew could train safely in weather conditions not unlike that of northern Europe.

Unlike the Rhodesians, the Canadians did not immediately jump at the possibility of closer cooperation with the British. While the Rhodesians were more than eager to allow the SRAF to become an adjunct to the RAF the Canadians were not prepared to let the Royal Canadian Air Force become an adjunct to the RAF. Recommendations by Group Captain J.M. Robb, Commanding Officer of the RAF's Central Flying School, to have an RAF scheme that would train 300 Canadian pilots a year was rejected by Canadian Prime Minister MacKenzieKing. He felt that such a scheme would not only be a drain on Canadian manpower, but from the point of view of Canada's national pride, Canadians serving in the RAF would be denied their own identity as

\footnotetext{
${ }^{17}$ See Harold Faber's Luftwaffe, An analys is by former Luftwaffe generals for a more complete analysis. "Hitler was not much interested in air power and left Göring a free hand as long as things went well. After the period of spectacular initial success, Göring suffered a sharp decline in influence, and the Führer interjected himself into the Luftwaffe's management. He was not helpful; his decisions were the product of ignorance and favoritism and simply completed the process of demoralization." p. xvi.

${ }^{18}$ Hugh Morgan, By the Seat of Your Pants, p. 39.
} 
had been the case in the First World War. ${ }^{19}$

If the Second World War was one of those events that further defined the national identity of the older Dominions, it seems to have bound Rhodesians emotionally closer to Britain, while at the same time giving greater definition to a Rhodesian identity. While the Canadians were balking at the thought of more British military influence, the Southern Rhodesian government offered to establish two more flight schools which would have brought the total number in the colony to twelve. This was turned down by the RAF who were anxious that the Canadian connection be developed as they had their eye on a potential link with the United States and the obvious benefits that this could offer. ${ }^{20}$

The RAF became an umbrella organization that accepted personnel from the Empire and integrated them into their own formations without necessarily concentrating men in units according to nationality. While this integration took place, squadrons that had a large number of one or other nationality, be they Americans, Czechs, Belgians, Canadians or others, would be given a nationality title after the squadron's number. Thus it was that while Southern Rhodesia started the war with one training squadron there were, in all, enough Rhodesians to man three RAF squadrons, although with casualties and the ebb and flow of personnel, it was not always possible to maintain

\footnotetext{
${ }^{19}$ Hugh Morgan, By the Seat of Your Pants, p. 39.

${ }^{20}$ Hugh Morgan, By the Seat of Your Pants, p. 14.
} 
complete national identity within the squadrons. ${ }^{21}$ The only identifying difference between members of the RAF were the shoulder flashes which gave the name of the country of the uniform's wearer.

In January, 1940, Southern Rhodesia's Government Gazette announced that a Department of Air, separate from the Ministry of Defense, would come into being. "The Department of Air is now completely separate from that of Defense. All administration and command of the Air Force will eventually be undertaken by RAF and SRAF personnel."22 In March 1940 Lt. Col. Lucas Guest was appointed Air Minister of Southern Rhodesia. On the 17th of January 1941, after eighteen months of war, the Rhodesia Herald reported that:

In the Air Force there were 1,416, including 17 trained pilots in [Southern] Rhodesia as instructors and in the communication squadrons, and 92 pilots outside the Colony and 259 men in training. There were also 64 Rhodesians waiting their turn to be absorbed in the Empire training schools. ${ }^{23}$

Given that Southern Rhodesia barely had any airplanes until the SRAU was established, the EATP was instrumental in establishing for the SRAF the complete range of training currently on offer by the RAF.

Essentially all the schools were controlled by the Rhodesian Air Training Group based at Salisbury who were in close working contact with representatives from the Air Ministry in London,

${ }^{21}$ They were: 266 (Rhodesia) Squadron, RAF, formed at Sutton Bridge, Lincolnshire on 30th October 1939; No. 1 (Cadre) Squadron, SRAF was redesignated in Kenya as 237 (Rhodesia) Squadron, RAF on 22nd April 1940. These were fighter squadrons and Ian Smith served with 237 Squadron. No. 44 (Rhodesia) Squadron, RAF, a bomber squadron, was formed in March 1937, but was given the "Rhodesia" title in September, 1941 because, like 266 Squadron, there were so many Rhodesians being posted there. 237 Squadron was the only unit that was originally part of the SRAF. J.F. MacDonald, The War History of Southern Rhodesia, 1939-1945, Vol. 1, pp. 33, 60, 231 232.

${ }^{22}$ J.F. MacDonald, The War History of Southern Rhodesia, 1939-45, Vol. 1, p. 33.

${ }^{23}$ J.F. MacDonald, The War History of Southern Rhodesia, 1939-45, Vol. 1, pp. 172-173. 
although in theory, they were directed by the Minister of Air of the Southern Rhodesian Government. ${ }^{24}$

From the bureaucratic form-filling of the Air Crew Reception Center (ACRC), to the Initial Training Wing (ITW) where prospective cadet pilots were screened, before being moved into a flight 'Grading' course held at an Elementary Flying Training School (EFTS) Southern Rhodesia had the full gamut of facilities and personnel. ${ }^{25}$ Advanced training was held at one of the Service Flying Training School (SFTS) and the instructors came from the Flying Instructor School, previously named the Central Flying School, which took pilots who were "resting" or in-between operational assignments as well as graduates from the Southern Rhodesian flight schools. ${ }^{26}$ By the end of the war approximately 9,900 personnel from all over the British Empire (7,600 pilots and 2,300 air crew) had been trained in Southern Rhodesia for the RAF in ten stations dotted around the country from the time the first training station was opened in May 1940 until April 1946 when the last station was closed. ${ }^{27}$ In all, 2,409 Rhodesians served in the RAF during the War. ${ }^{28}$

\footnotetext{
${ }^{24}$ Hugh Morgan, By the Seat of Your Pants, p. 1.

${ }^{25}$ Hugh Morgan, By the Seat of Your Pants, p. 13.

${ }^{26}$ Hugh Morgan, By the Seat of Your Pants, pp. $21-22$.

${ }^{27}$ The flight schools were clustered around Salisbury, Bulawayo, and Gwelo and evenly divided between EFTS and SFTS. The EFTSs were at Belvedere (25 EFTS), Guinea Fowl (26 EFTS), Induna (27 EFTS), Mount Hampden (28 EFTS), and the ITW at Hillside. The SFTSs were at Cranborne (20 SFTS), Kumalo (21 SFTS), Thornhill (22 SFTS), Heany (23 SFTS) and Norton (33 FIS), map facing p. 32. Hugh Morgan, By the Seat of Your Pants, p. 33.
}

${ }^{28}$ There were 977 Officers and 1,432 'Other Ranks' from Southern Rhodesia in the RAF. The War History of Southern Rhodesia, 1939-45, Vol. 2, Appendix, p. i. 
The importance of the SRAF to the Allied war effort is significant for the operational and organizational experience gained for the future Rhodesian Air Force. When the Rhodesian Air Training Group, which had been the organization under which the EATP had functioned in Southern Rhodesia, closed down in 1947, the SRAF was reconstituted. Simultaneously, a Southern Rhodesia Auxiliary Air Force was created to provide continuation training for RAF veterans as well as the next generation of Rhodesian pilots, so that there was no break in continuity. ${ }^{29}$ In October 1954, after the formation of the Federation the SRAF became the Royal Rhodesian Air Force (RRAF). The RRAF was, in its turn, organizationally separated from the Army to become a service in its own right in $1956 .{ }^{30}$ It should be mentioned that the Rhodesian Air Force was an overwhelmingly white organization throughout its history and remained so for a time even after Rhodesia became Zimbabwe.

${ }^{29}$ Brelsford, Handbook to the Federation of Rhodesia and Nyasaland, p. 673.

${ }^{30}$ "Her Majesty The Queen was graciously pleased to approve the addition of the prefix 'Royal' to the name of the Rhodesian Air Force..." A Brief History of the Rhodesia Army, p. 14. 


\title{
CHAPTER X
}

\author{
DIFFICULT ALLIES; \\ South Africa, Southern Rhodesia and the Second World War
}

The question that begs answering is why Southern Rhodesia, South Africa and Britain did not bind themselves sooner in an alliance to face the common threat posed by Italian ambitions. The simple answer is that South Africa was not that friendly with Britain despite her being a British Dominion. It is also worth while pointing out that the German threat was not seen as that important or relevant to Afrikaner nationalists, very much as the position had been at the beginning of the First World War, and they were less than enthusiastic about lining up to defend British interests in Africa. It was only when the Axis menace began to appear to threaten South African interests that opinion among the nationalists shifted, but only slightly.

Relations between South Africa and Southern Rhodesia had never been close. If Rhodesians were wary of Africans with whom they had fought a little over forty years before, they were equally distrustful of much of what was going on in the Union, the rulers of which they had fought against more recently than they had fought the Ndebele and Mashona.

Rising Afrikaner nationalism had been one of the chief reasons for the Rhodesian electorate's rejection of incorporation of Southern Rhodesia into the Union as its fifth province in 1923, despite a 
generous offer by the South African Prime Minister Jan Smuts. ${ }^{1}$ The man who was to become the first Prime Minister of Southern Rhodesia, Sir Charles Coghlan, voiced the opinion of many British settlers in Africa when he told Winston Churchill, then Secretary of State for the Colonies, that...

'we in Rhodesia wished to have no part or lot (in the Union of South Africa) which had apparently the constitutional right, and so far as the Dutch element was concerned, all the will, to cut us adrift from the British flag', and he went on to startle the new Secretary of State with an assurance that "we will not part from the British flag without fighting'.2

The matter for Rhodesians was becoming complicated by the change in the assumptions of the Colonial Office on the subject of white settlement in Africa, a process that had been going on since the early post-First World War period. ${ }^{3}$ This was also the period when South African territorial acquisitiveness was at its height with the South African Party government under Smuts, fresh from the virtual incorporation of South West Africa into the Union, attempting and falling to entice Southern Rhodesia, and trying to annex the High Commission Territories. ${ }^{4}$ Smuts had hoped that the conquest of German East Africa by Union forces would lead Portugal to a territorial swap for southern Mozambique, so that South Africa could annex the

${ }^{1}$ T.R.H. Davenport, South Africa, A Modern History, p. 188.

${ }^{2}$ Oliver Ransford, The Rulers of Rhodesia, p. 310.

${ }^{3}$ See L.H. Gann, A History of Northern Rhodesia; Early Days to 1953, Chapter 8 for a more complete discussion of the question of Rhodesian Amalgamation and changing British attitudes.

${ }^{4}$ The British territories of Bechuanaland (present day Botswana), Basutoland (present day Lesotho), and Swaziland. Basutoland is surrounded by South Africa and Swaziland is virtually surrounded by South Africa. 
capital, Lourenço Marques (now Maputo) and the territory all the way up to Beira, which was Southern Rhodesia's port and rail outlet to the Indian Ocean. ${ }^{5}$ This in turn would have made the incorporation of Southern Rhodesia easier and logical.

In the last resort, these bids for territorial expansion had failed because Imperial support had been withdrawn. The new doctrine of paramountcy of African interests, which had been clearly expressed by the Duke of Devonshire in relation to Kenya in 1923, lay behind the British attitude. It formed no part of Smuts' vision, for Smuts had come to look upon the extension of 'a great White Africa along the Eastern backbone, with railway and road communications connecting north and south', as a necessary guarantee for the long-term security of the white south. ${ }^{6}$

Given the attitude of South Africa it was logical that Britain should turn to Southern Rhodesia for help and cooperation. Until the close military cooperation between Britain and Southern Rhodesia in the years leading up to the Second World War, as Major Hudson's Memorandum to the 1926 Defense Act pointed out, Southern Rhodesia's defense forces' only concern was internal security. Had there not been a threat from Italy, or had South Africa been closer to Britain sooner, it is entirely possible that Southern Rhodesia would not have acquired the military expertise that it did. The War Office, through the CID-ODC, not being affected by the growing concerns in the Colonial Office about settler states, naturally placed Southern Rhodesia in the context of an African defense strategy.

It is also possible that the British would have taken a less active interest in the kind of rationalization that it was attempting to impose

\footnotetext{
${ }^{5}$ T.R.H. Davenport, South Africa, A Modern History, pp. 189.

${ }^{6}$ T.R.H. Davenport, South Africa, A Modern History, pp. 190.
} 
on the various territories under her control and the post-Second World War Central African Federation may never have come into existence. In 1937 a Royal Commission under Lord Bledisloe, under the auspices of the Colonial Office, examined the possibility some type of closer political relationship between Southern Rhodesia, Northern Rhodesia and Nyasaland, which would have the effect of bringing political and military questions under one authority. The Bledisloe Commission was considering the possibility of a fusion of all three under Southern Rhodesia, or dividing Northern Rhodesia between Southern Rhodesia and Nyasaland or maintaining the political and administrative status quo, but with closer coordination of common services, such as customs, posts and telegraphs. ${ }^{7}$ The result of the policy of accommodating Rhodesian political aspirations may now seem strange, but the CID-ODC's attitude was, as previously stated, that...

Southern Rhodesia is predominantly an area for white settlement, and the African population, which is relatively small compared with that in Northern Rhodesia and Nyasaland, is mainly concentrated in native reserves. ${ }^{8}$

The CID-ODC was unconcerned with the political or social state of affairs in Southern Rhodesia. They were concerned with national security and Southern Rhodesia's rapid development into a minor but effective regional military power took precedence and could only be for the good. This concern extended to Southern Rhodesia's preoccupation about raising African units. The success of the RAR may

\footnotetext{
${ }^{7}$ ODC Minute No. 300,1938 , p. 7. PRO CAB 10/9.

${ }^{8}$ ODC Minute No. 300,1938 , p. 1. PRO CAB 10/9.
} 
have had an additional beneficial effect on the willingness of the British to the establishment of the Federation:

The Oversea Defense Committee consider that whatever decision is finally taken regarding the closer association of the three Territories, their defensive organization must continue to provide coordinated arrangements to ensure the maintenance of local internal security, resistance to invasion, and the maximum possible support to other African dependencies in the event of attack by a hostile Power, or of internal disorder on a large scale.

The Committee are of the opinion that this can only be achieved by the retention of the existing African units, upon which the coordination of defense in East and Central Africa depends, and by adequate measures for the training of white leaders. ${ }^{9}$

When the war came both Southern and Northern Rhodesia were profiting as much from the war in terms of economic growth as well as the alliance with Britain. The military demand for Northern Rhodesian copper, and other strategic materials, was such that the British established a Ministry of Supply in 1939 in order to conclude bulk agreements with producers. ${ }^{10}$ While it took copper out of the free market for the duration of the war, it also guaranteed Northern Rhodesia a stable market and made the necessity of a happy relationship between Rhodesians and the British a matter of national importance, which can only have increased their political leverage.

When, in 1940, the governments of Northern Rhodesia and Nyasaland decided that they wanted no part of a proposed East African Economic Council deciding instead that their interests lay in a closer association with Southern Rhodesia, they were encouraged by the Dominion Office “...which stressed Southern Rhodesia's fine war

\footnotetext{
${ }^{9}$ ODC Minute No. 300,1938, p. 8. PRO CAB 10/9.

${ }^{10}$ L.H. Gann, A History of Northern Rhodesia; Early Days to 1953, p. 329.
} 
effort, and the need not to alienate Huggins, and also from Sir Henry Moore, the Governor of Kenya, who was perturbed about the growth of Union [of South Africa] influence in East Africa." ${ }^{11}$ This attitude also went against the continuing evolution of the Colonial Office's attitude about the 'paramountcy' of African over settler interests. The attitude of the British political left had also been changing in its attitude towards settlers so that by the time the Bledisloe Commission, which was to decide the future of Rhodesian union, came out, it "...'funked the issue' on all the essentials." ${ }^{2}$ The report seems to have been an exercise in recapping the political, social and economic policies and issues of the three territories without recommending any radical changes in the status quo. Opinion within the Bledisloe Commission was not unanimous and the ideas of fusion and federation reflected some of the changed attitudes and foreshadowed the controversy that would welcome the creation of the Federation the end of the war:

...Orr Ewing on the other hand considered amalgamation desirable but not inevitable, whereas Fitzgerald, a Colonial Office man to the core, felt that His Majesty's Government should not as yet commit itself to the principle of amalgamation, in view of the alleged failings of Southern Rhodesian native policies. ${ }^{13}$

Britain's intimacy with the Rhodesians contrasted sharply with the lack of a relationship with South Africa. Opinion within the Union was sharply divided over involvement in the war, but it was vital for Britain that the various strategic assets of South Africa become part of the Allied cause. Not only did the Union control the route around the

${ }^{11}$ L.H. Gann, A History of Northern Rhodesia; Early Days to 1953, p. 353.

${ }^{12}$ L.H. Gann, A History of Northern Rhodesia; Early Days to 1953 , p. 276.

${ }^{13}$ L.H. Gann, A History of Northern Rhodesia; Early Days to 1953, p. 276. 
Cape, between east and west, at a time when the Suez Canal was under threat by the war in Egypt and Libya, but South Africa was a source of raw materials. It was the most important gold producer in the Sterling area, and had a well-developed industrial base. ${ }^{14}$

South Africa, with its much larger white population, had an army, an air force and a navy. ${ }^{15}$ The Union Defense Force (UDF) was, despite Colored (mixed race) and Asian support units, a white fighting force. During the Second World War the UDF fielded two full army divisions, one of which, the 6th (South African) Armored Division, was one of the largest Allied formations of the war.

The man in charge of South Africa during the war was the legendary Boer War Commando leader, Jan Smuts who had been South African Prime Minister once before from 1919 to 1924 and had tried to entice Southern Rhodesia into the Union. ${ }^{16}$ Once again, a campaign was afoot, of uncertain intensity, to expand South Africa's influence northward.

'Pan-Africanism' was in the air, but Pan-Africanism in Southern Africa was then mainly used to denote a white man's cause, involving the extension of the Union's influence beyond its borders, and the creation of larger territorial units, concepts which were put forward especially by Smuts' adherents in the

${ }^{14}$ L.H. Gann, A History of Northern Rhodesia; Early Days to 1953, p. 353.

${ }^{15}$ The South African Air Force (SAAF), whose members served in the Western Desert and Italy in the RAF, did not use the title 'Royal' like the other Dominions' Air Forces and it used the army, as opposed to the RAF, rank structure.

16 "In August 1922 Smuts made what seemed to him a successful tour of [Southern] Rhodesia, although many Rhodesians thought he should have kept away from an issue they regarded as domestic. There was general hilarity when he asserted he had come but as a simple tourist. It made him realize however that his prospects were not good: "They are afraid of our bilingualism, our nationalism, my views of the British Empire. In short they are little Jingoes'." Ronald Hyam, The Failure of South African Expansion, 1908-1948, p. 67. 
Afrikaans propaganda. ${ }^{17}$

Britain and South Africa were also still involved in their long running dispute about the future of the High Commission Territories, although Smuts was not as anxious as he had once been to see them joined to the Union. "In 1943 Smuts showed no disposition to raise the issue, agreeing that it should definitely be suspended." ${ }^{18}$ Bringing it up during the war, given Britain's precarious position and the relative military strength of South Africa would only worry the Rhodesians, whom he was anxious not to alienate despite their newfound friendship. He hoped that at the end of the war South Africa "could bring widespread administrative and territorial changes in Africa." ${ }^{19}$ although it does not seem to have been spelled out in any detail other than a vague hope.

Posing as an 'African apostle', determined to promote 'African interests' and development to the north in the interests of all races, he envisaged the possibility of some vast federal structure rivaling the United States of America. If he could induce Britain to link up some of her 'fragments' in east and central Africa, a new large state to the north might be coaxed into partnership with South Africa. In such a scheme, the High Commission Territories were relatively small and unimportant, and he was perhaps genuinely concerned not to let them develop into a bone of contention. ${ }^{20}$

The goodwill of the Union's contribution towards the war effort could only have been offset by these disputes. They can only have

\footnotetext{
${ }^{17}$ L.H. Gann, A History of Northern Rhodesia; Early Days to 1953, p. 353.

${ }^{18}$ Ronald Hyam, The Failure of South African Expansion, 1908-1948, p. 175.

${ }^{19}$ Ronald Hyam, The Failure of South African Expansion, 1908-1948, p. 175.

${ }^{20}$ Ronald Hyam, The Failure of South African Expansion, 1908-1948, p. 175.
} 
helped the British to decide that the best way of countering any Afrikaner ambitions was the counter-balance of a united Rhodesia, which had been so faithful for so long. Smuts' hopes were in vain; in 1948 his government fell, the Nationalist Party under Dr. Daniel F. Malan came to power, and the Rhodesian dream of dominion status saw brief light with the creation of the Federation of Rhodesia and Nyasaland in 1953.

The lack of cooperation and hostility by a large portion of Afrikaners is also illustrated by the 1934 visit to South Africa of Sir Maurice Hankey, Chairman of the Committee of Imperial Defense, while on a trip to Australia and New Zealand. He received such a hostile reception from the nationalist Afrikaans press, suspicious that South Africa would become involved once again in a British-led war, that he insisted that the visit was private, as his wife was South African. A 'courtesy' call on Prime Minister J.B.M. Hertzog did not put the right wing press off the scent. In a letter to the British High Commissioner, Sir Herbert J. Stanley, Hankey expressed a desire to speak to Hertzog on the subject of defense, especially British air defense proposals:

At their last meeting before the Parliamentary Adjournment the Cabinet instructed me to see the Prime Minister of each of the Dominions during my visit and to communicate personally how the Inquiry on Imperial Defense now stands.

Whereas in my former letters I was only asking to see General Hertzog for personal reasons, I now have to make to him a rather important communication in connection with the above subject. I should be much obliged, therefore, if you could arrange that, if possible, I should have rather a long interview. If General Hertzog is not in Pretoria I would, of course, go to his farm, or to anywhere else to see him.

I do not know whether it will be necessary for you to tell him the subject on which I am to speak to him. It has occurred to me, after hearing of the effect in the Press of the Durban Naval 
Visit and Conference, that possibly it would be more convenient not to mention the subject to General Hertzog unless it is necessary. But you will be the best judge of that. ${ }^{21}$

The Nationalists, however, became worried about German and Italian intentions in Africa during the late 1930s, especially after Italy had conquered and annexed Ethiopia in 1935-36. Italian Somaliland, Eritrea and Ethiopia were joined together to form the single entity of Italian East Africa which all but surrounded British Somaliland and covered almost the entire northern border of Kenya. Germany, now well under the control of Adolf Hitler, was making noises about the return of Tanganyika and South West Africa, both League of Nation mandate territories, with the latter all but incorporated into the Union of South Africa.

The Union's Minister of Defense, Oswald Pirow, however “...a personable white supremacist and versatile outdoor man..."22 was, like many members of the National Party, mesmerized by Nazi Germany, so that even while the Union declared war on Germany, there were many South Africans, like Pirow, who took the attitude that South Africa should have no part in the war:

...whites who felt that the preservation of the existing race-caste structure was necessary for European survival in the subcontinent, or who were emotionally drawn to the Germans as to near-kinsmen, or who were excited by the energy or the doctrines of Nazi Germany, either backed the Axis or demanded a return to neutrality. ${ }^{23}$

\footnotetext{
${ }^{21}$ Commonwealth Defense Co-operation: visit of Sir Maurice Hankey to Dominions, 1934. PRO DO 119/1048

${ }^{22}$ T.R.H. Davenport, South Africa, A Modern History, p. 215.

${ }^{23}$ T.R.H. Davenport, South Africa, A Modern History, p. 234.
} 
Pirow, however, expressed worries about the possibility of having to return South West Africa to Germany and having a potential enemy just across the border:

$\mathrm{He}$ is in the best positions for knowing that South Africa will dig her toes in to the last over German South West, but he is afraid that we might be chivalrous about Tanganyika. If that were to happen, having no illusions about his German kinsmen, he realizes that the Union would have a constant menace from the north-east. he points out that Kenya would be between the upper and nether millstones as between Italy and Germany and he has at one time or another touched upon the possibilities of a defense conference between the Union and our Central African Colonial Governments. In fact we recently reported to the Dominions Office that Pirow had mentioned to the Naval Intelligence Officer that he proposed to take the opportunity provided by the forthcoming Pan-African Transportation Conference to discuss defense issues. ${ }^{24}$

South Africa's entry into the war in September 1939 was not a forgone conclusion. Prime Minister Hertzog pushed for South African neutrality and Smuts, the Deputy Prime Minister, pushed for a declaration of war. The vote in the South African parliament that brought defeat for Hertzog and Smuts to power as Prime Minister for the second time in his career and war with Germany, did not completely reassure Britain that South Africa was a completely safe ally, especially in the early days of the war when German victory was not uncertain.

An example of British concern was shown in a "Secret and Personal" letter written on the 4th of September, 1940 by General Sir Archibald Wavell, then the British commander in Egypt, to the High Commissioner in Pretoria, Sir Edward Harding. In it he asks Harding

${ }^{24}$ Secret Letter from Sir W.H. Clark to the Governor of Southern Rhodesia, Sir H.J. Stanley, 22 April 1936. PRO CAB 21/642. 
to send him...

...periodical reports on the political situation in South Africa and the general feeling there, particularly in regard to military matters. With South African troops in my Command I should like to know how you think things are going and what difficulties Smuts is having. A short report from you every two or three weeks would be most valuable. ${ }^{25}$

In his reply Harding promises to send periodic reports, but feels that he can not forward copies to Kenya where the British had set up an intelligence gathering operation because:

...there is such close coordination between the Union and United Kingdom forces in Kenya that it is possible that some of these reports might come to the notice of Union officers. As the reports made from time to time contain forecasts of the policy of the Union Government based on information obtained in confidence, or comments on members of the Union Government, or on Union officials, it is highly desirable that there should be no possibility of this happening. ${ }^{26}$

After giving an overview of the situation of families of servicemen who had been evacuated to South Africa, the harmonious relationship between the British forces and the UDF, Harding concludes:

Smuts is himself convinced that he now has the internal situation well in hand. The civilian population has been disarmed; he has in all over 105,000 men, all of them volunteers, in the military forces; and the actively hostile elements are disunited. But while the great majority of the opposition would not be likely to convert words into deeds, there is a reckless minority of extremists who are concentrating on stirring up trouble however and wherever they can, and particularly in the Mines.

The difficulty in the Mineworkers' Union, as in the public service and the railways is, of course, that the most loyal elements have now joined up, and that the proportion of hostile elements is, therefore larger than at the beginning of the war. And the extremists are succeeding in stirring up more real feelings of bitterness than have prevailed here for many years.

\footnotetext{
${ }^{25}$ Letter from Wavell to Harding, 4 September 1940. PRO DO 119/1134

${ }^{26}$ Letter from Harding to Wavell, 12 October 1940. PRO DO 119/1134
} 
So long, however, as Smuts remains in control there is probably no need to worry unduly about South Africa. The danger of course is the extent to which everything depends on one man, comparatively old in years but, as you know, exceedingly young in mind and spirit. ${ }^{27}$

Despite the simmering hostility from the Afrikaner right, the change of atmosphere was immediately noticed by the British and the Rhodesians as the new South African administration communicated their desire to meet with Rhodesian Prime Minister Huggins “...to clear up petty difficulties which have been an irritating factor in relations between Union and Southern Rhodesia under the Hertzog regime." and "...to establish a firm basis of cooperation between the two Governments in the event of trouble in North Africa."

Prime Minister [Smuts], he said, was well aware of distrust aroused in Southern Rhodesia by ambiguous attitude of Union Government in recent years and was anxious to do his best by following a good neighbor policy to repair the damage done in the past and to build up a new feeling of confidence between the two countries for the future. Prime Minister hoped that, now that the show down had occurred in the Union and had resulted in placing in power a Government resolutely opposed to any weakening of the Union's position as a member of the British Commonwealth, there would be a ready response from Southern Rhodesia. ${ }^{28}$

Even while these encouraging words were being communicated, Sir W.H. Clark's telegram went on to reassure the British that fears of South African motivations were not justified:

I do not think that there is any reason for apprehension that Prime Minister's motives go further than this, i.e. that he has in mind possibility that presence of South African troops in Central and East Africa in time of war might be used to enforce a claim for closer connection later. (After all, South African troops

${ }^{27}$ Letter from Harding to Wavell, 12 October 1940. PRO DO 119/1134

${ }^{28}$ Telegram from the High Commissioner, Pretoria to the Secretary of State, London 20 November 1939. PRO DO 119/1114. 
fought in East Africa in last war). Some of his followers, I know, look to Southern Rhodesia whose incorporation in the Union would they consider remove for all time all possibility of Dutch [Afrikaner] ascendancy (and this feeling may become increasingly strong as the war develops)...

Would you please communicate this to Stanley [Southern Rhodesia's governor] since I possess no cipher for communicating with him which Union Government do not also hold... ${ }^{29}$

Smuts, always the diplomat, reassured the Rhodesians that the... "Main object in inviting Prime Minister of Southern Rhodesia to pay a visit to Pretoria was to pave the way for improved relations... and to secure closer cooperation particularly in defense matters. There was no intention of forcing the pace in the discussions which it was agreed should be purely exploratory." 30 The resulting visit on the 27 th of November to Pretoria by Prime Minister Huggins and Defense Minister Tredgold was a success... "They seem to have been agreeably impressed with the change of atmosphere (as affecting Southern Rhodesia) which has taken place since the Smuts regime came into being." 31

After the outbreak of war, it soon became obvious that the Union of South Africa would play an important part in Southern Rhodesia's military history and development. With the Allied victory in North Africa and the reduction of the Japanese threat in the Indian Ocean by the end of 1943, the danger of the Colony becoming directly involved

\footnotetext{
${ }^{29}$ Telegram from the High Commissioner, Pretoria to the Secretary of State, London 20 November 1939. PRO DO 119/1114.

${ }^{30}$ Telegram No. 372 from the High Commissioner, Pretoria to the Secretary of State, London 8 December 1939. PRO DO 119/1114.

${ }^{31}$ Telegram No. 397/39 from the High Commissioner, Pretoria to the Secretary of State, London 14 December 1939. PRO DO 119/1114.
} 
in the war had all but vanished. A change in direction for Southern Rhodesia's soldiers was imminent. "For some considerable time there had been a growing feeling amongst Rhodesians serving in the Imperial forces, that they would prefer to be allowed to serve in the Union Defense Force." ${ }^{32}$

The negotiations with the UDF had been going on for many weeks in Pretoria and Salisbury. "It was there agreed that there should be no overlapping in the Commands of South and East Africa and that Southern Rhodesia should throw in her lot with one or the other." ${ }^{33}$ Cooperation with the UDF was not new and had been under way since the Union entered the war in 1939 and was readily acknowledged by Southern Rhodesia's Military Forces Commander, Brigadier J.W. Watson...

We have worked on it for the past three years, admittedly in order to get a sound and balanced scheme of local defense embracing Northern Rhodesia and Nyasaland, the Union and Southern Rhodesia. This seemed such an obvious requirement to me that I never hesitated to pursue it. It must be very clear that in the case of attack on this country which might have occurred earlier in the war, though it is remote now, we should have been dependent on the Union for a great deal of assistance in many directions. ${ }^{34}$

A second reason was cost. Drafting their men through the UDF meant that Southern Rhodesia would not have to foot the bill for transporting their soldiers to the nearest British units, which had

\footnotetext{
${ }^{32}$ Report on Defense for 1943 , p. 71 . Southern Rhodesia Annual Report on Defense for 1939-45. British Library.

${ }^{33}$ J.F. MacDonald, The War History of Southern Rhodesia, 1939-45, Vol. 2, pp. 367-368. 371.

${ }^{34}$ J.F. MacDonald, The War History of Southern Rhodesia, 1939-45, Vol. 2, p.
} 
been in Kenya and Egypt.

Without exact figures, which I can obtain if necessary, they amount to approximately $£ 100,000$ so far during this war. Not only are we responsible for sending our men to the British Army but we pay all expenses of bringing them back. This is unlikely to be the case with the Union. ${ }^{35}$

The positive aspects of the British connection were obvious.

There were no guarantees that Rhodesians would have had the military exposure in the UDF that they were having through serving with the Imperial forces because of the agreements that they had had with the British in the years before the war:

I am not disagreeing with past policy. It was right and I supported it fully, for it has enabled us to place nearly 600 Rhodesians as commissioned officers in all sorts of Units in various commands. This would never have been possible had we sent large units of our own men on active service. Of course, this may well be accepted as a reason for not sending large units now, but the position in regard to the supply of leaders is not quite so pressing as it was...

It would appear that the Southern Rhodesian government was going to have everything its own way. The experience gained in the African Colonial forces could never have been achieved by allying themselves with the UDF. It is possible that the RAR would never have been formed and the political implications of such an early association with the South Africans might have hardened some British attitudes, even on the political right, about the viability of a central African federation based on Southern Rhodesia.

It had also become apparent that not all Rhodesians would be 371.
${ }^{35}$ J.F. MacDonald, The War History of Southern Rhodesia, 1939-45, Vol. 2, p.
${ }^{36}$ J.F. MacDonald, The War History of Southern Rhodesia, 1939-45, Vol. 2, pp. 
suitable as leaders, especially where African soldiers were concerned, and that a place should be found for them. The ability to communicate with and lead soldiers into war across cultural, ethnic and social barriers requires special talents.

...we are accumulating a fairly large number of men who will probably never be suitable for commissions during this war. It is for these men that we must cater now and endeavor to improve their conditions and satisfy their desire to serve together in Rhodesian units. ${ }^{37}$

Three reasons were outlined by the 1943 Defense Report which made no mention, except in passing, of a minor clash of cultures:

(i) a greater affinity of Rhodesian soldiers for the Colonial troops in the 1st South African Division than existed between them and the Imperial troops with whom they had served;

(ii) conditions of service in the UDF, which were more attractive to Rhodesians than were conditions of service in the Imperial Army.

(iii) a better opportunity for Rhodesians to return to the Colony on leave if they were members of the UDF. ${ }^{38}$

There seems to have been some friction between some Rhodesians and their British hosts. ${ }^{39}$ When Rhodesians were withdrawn from British units to be sent to South African units, the parting was not always regretted... "Some had felt most unhappy on account of the air of cold aloofness and indifference with which a 369-370.

${ }^{37}$ J.F. MacDonald, The War History of Southern Rhodesia, 1939-45, Vol. 2, pp.

${ }^{38}$ Report on Defense for 1943 , p. 71 . Southern Rhodesia Annual Report on Defense for 1939-45. British Library.

39 "In an accent-and class-conscious society, the Rhodesian accent was not highly esteemed in a British officers' mess of the traditional kind. ... Regular soldiers in the ranks, on the other hand, widely came from the unskilled working class; white Rhodesian workers were all skilled." Letter from Dr. L.H. Gann, dated September 9th, 1994. 
small-minded minority of Regular officers met their friendly advances. ${ }^{\circ 0}$ Some were finding that service with the British Army was not to their liking, "All evidence both direct and collateral indicates a desire on the part of at least 80 percent of Southern Rhodesians in Middle East to transfer to the Union forces..."

Unless we enter fully into the Union scheme we are going to serve two masters, i.e., the British Army and the Union Defense Force. Unsatisfactory from many points of view, but a most fertile source of complaint from our men on active service. I am satisfied from letters I have received and conversations I have had that by placing all those who wish to go with the Union Defense Forces on active service, we shall remove, at any rate for a considerable period, the masses of grouses which we receive from our men serving in penny packets all over the Middle East. $^{42}$

Rhodesians would be sent to the 6th (South African) Armored Division, which was being formed in the Union after the withdrawal of the 1st (South African) Division from North Africa in 1943. "The time, therefore, appeared opportune, if the policy were approved, not only to transfer Rhodesians serving in Imperial Forces to the UDF but also to draft all available men serving in the Colony to the UDF for inclusion in the new armored division" 43

The aim was to secure "...Rhodesian armored squadrons in armored regiments, Rhodesian batteries in field and anti-tank 155.

${ }^{40}$ J.F. MacDonald, The War History of Southern Rhodesia, 1939-45, Vol. 1, p.

${ }^{41}$ J.F. MacDonald, The War History of Southern Rhodesia, 1939-45, Vol. 2, pp. 369-370.

${ }^{42}$ J.F. MacDonald, The War History of Southern Rhodesia, 1939-45, Vol. 2, pp. 369-370.

${ }^{43}$ Report on Defense for 1943 , p. 71 . Southern Rhodesia Annual Report on Defense for 1939-45. British Library. 
regiments of artillery and Rhodesian companies in motor battalions." The fact that it was to be a voluntary decision, whether to transfer or not, meant that it was not always possible to keep Rhodesian units completely Rhodesian in character. Those Rhodesians who were in specialist roles would be sworn into the UDF and allowed to stay in the units they were already serving in. ${ }^{45}$

The Southern Rhodesian Director of Demobilization, Mr. William Addison, further reflected this reason for extending the relationship to South Africa. Sending Rhodesians to the UDF would satisfy those 'cultural' needs of Rhodesian soldiers who, despite their pro-British feelings and identity, came from the same background as the South Africans:

From my own experience, backed by the opinions of men with much closer and longer knowledge than myself, it would appear the war has thrown up a distinct Rhodesian type. He is in some respects different from the other Empire soldiers, and is naturally nearest to the South African and closely allied to the New Zealander, with whom in the desert there has always been frequent, close and happy contact. Not always, it must be admitted, has the contact between Rhodesians and certain types of the British Regular Officer and the prewar British Tommy been of the same harmonious nature.... ${ }^{4}$

There was, however, still a fear of the Afrikaner-dominated Union and the public had to be reassured, as the Bulawayo Chronicle of October 28th, 1942 pointed out, that an alliance with the Union would

\footnotetext{
${ }^{44}$ Report on Defense for 1943, p. 71 . Southern Rhodesia Annual Report on Defense for 1939-45. British Library.

${ }^{45}$ Report on Defense for 1943, p. 71 . Southern Rhodesia Annual Report on Defense for 1939-45. British Library.

${ }^{46}$ J.F. MacDonald, The War History of Southern Rhodesia, 1939-45, Vol. 2, pp. 368-369.
} 
not mean the end of Southern Rhodesia's independence:

The Minister was at pains to explain that the change does not mean that 'in a military sense this Colony has been handed over bodily to the Union.' We do not believe there is any public fear on this score; it will be taken for granted that the military authorities of the Union will deal with the question of the defense of South Africa - or with any other military matters which may have to be decided - on the agreed basis of negotiation and arrangement. The decision taken is the obvious sound and sensible one from a military point of view, and that point of view was the one which should have and obviously was predominant. We share the Minister's view that 'it will be a source of great satisfaction to the Colony that from now onwards the general direction of its military affairs will be in the hands of one of the greatest soldiers and statesmen of our day, but quite apart from the fact that Field Marshal Smuts is at the head of the Command, the wisest course was followed by our Government in doing what it did. ${ }^{47}$

Whether fortuitously or by design, Southern Rhodesia emerged from the Second World War in a very strong position to press forward with its agenda to become another Dominion in a federal relationship with Northern Rhodesia and Nyasaland. How much the British would have been willing to allow Rhodesians to take the path that they followed had the two world wars never occurred is hard to say. What is certain is that the strategic relationship between the two benefited both sides and Rhodesia, on both sides of the Zambezi, emerged in a very strong position; militarily, economically and politically.

${ }^{47}$ J.F. MacDonald, The War History of Southern Rhodesia, 1939-45, Vol. 2, pp. $371-372$. 


\section{CHAPTER XI}

\section{CONCLUSION;}

the Beginning of the End

The Federation of Rhodesia and Nyasaland was the high tide of Rhodesian aspirations when it was inaugurated in 1953. The Rhodesia and Nyasaland Army and RRAF cooperated closely with Britain throughout the decade of the 1950s, in fact the entire regular infantry strength and a small white volunteer unit of the Army served under British command in the Malayan Emergency. There were joint exercises and most of the junior officers of the period received their initial training at Sandhurst. All of this gave Rhodesian soldiers considerable exposure and experience beyond what they already had from the Second World War.

For all of the experience of its units and individuals in the period leading up to UDI, the army had never operated as a force under a single command structure. It had always been an adjunct to a larger British or South African force. This is probably one of the reasons why its record in the Chimurenga War was so inconsistent,

\footnotetext{
${ }^{1} 1$ NRR was in Malaya from 1954 to 1955,1 RAR from 1956 to 1958 . The Nyasaland battalions of the King's African Rifles ( $1 \& 2 \mathrm{KAR}$ ) served in Malaya from 1950 to 1952 and from 1952 to 1954 respectively. W.V. Brelsford, Handbook to the Federation of Rhodesia and Nyasaland, p. 670. The Southern Rhodesia Far East Volunteer Unit, which became 'C' (Rhodesia) Squadron, 22 SAS Regiment, served in Malaya from 1951 to 1953 . B. Cole, The Elite, pp. 7-13.
} 
with its strengths lying at the tactical rather than the strategic level. ${ }^{2}$ The Staff Corps never became the kind of intellectual clearing house for ideas that it could have been, and this can be seen by its origins, which has been pointed out, as a system that "...served a static geographic spread by an admixture of BSAP and civil service procedures." 3

This tradition of flexibility at unit level contrasted with organizational weaknesses, many of which had their origins in the formative period of the Army's history. The Rhodesian Army was hampered by the fact that it was never the senior service and was regarded as the nation's second line of defense after the BSAP. Where the Army's needs and wishes competed with those of the police, especially in the area of intelligence gathering, the Army lost. The fact of being 'the second son' meant that military intelligence was a key area where the army failed. Simply stated, there was no tradition of military intelligence in Southern Rhodesia's Army. ${ }^{4}$ No such unit was raised in Southern Rhodesia for the Imperial war effort, with the result that no tradition was established of having one in the Army after the war. Tactical intelligence was gleaned from BSAP and police

\footnotetext{
${ }^{2}$ Hoffman, Taw \& Arnold, Lessons for Contemporary Counterinsurgencies, pp. 13-18.

${ }^{3}$ Letter from Colonel Welch dated August 28, 1993.

4 "Internal security and intelligence gathering remained the responsibility of the police Special Branch throughout the counterinsurgency campaign because of the symbiotic relationship between intelligence gathering operations and routine police investigation work." Hoffman, Taw \& Arnold, Lessons for Contemporary

Counterinsurgencies, p. 30.
} 
Special Branch sources. ${ }^{5}$

It is also interesting to note that the Rhodesian units raised during the Second World War reflected the expertise of Rhodesia's federal and later republican army. The armored and artillery capabilities and traditions of the Rhodesian Army are a case in point. It is not entirely certain how valuable they were, either in the Chimurenga War or before it in the federal period, but as both units had an existence, it gave them a constituency. The Governor-General's Troop, the Rhodesia and Nyasaland Artillery, was added to the Defense Force for ceremonial purposes in 1959 because...

The late Lord Llewellin, himself a "Gunner", had first suggested the formation of a Governor-General's Troop, on the style of the King's Troop, The Royal Horse Artillery, in the British Army. ${ }^{6}$

An argument can be made that they would have been useful had the war become a conventional conflict. The final reincarnation of these two battalion-sized units as 1 Field Regiment, Rhodesian Artillery (1 FR) and the Rhodesian Armored Car Regiment (RhACR) had very little impact on the conduct of the Chimurenga War, despite their illustrious and useful record in the Second World War. Rhodesia's final struggle was, in fact, conducted by small, special force and light infantry units transported and deployed from the air and using close

\footnotetext{
"One of the greatest weaknesses of the Rhodesian counterinsurgency campaign was its lack of emphasis on military intelligence." and "The Army developed no real independent intelligence capabilities and, until 1975, relied completely on Special Branch." Hoffman, Taw \& Arnold, Lessons for Contemporary Counterinsurgencies, p. 28.

${ }^{6}$ Breslsford, The Handbook of Rhodesia and Nyasaland, p. 674.
} 
air support.?

Because Southern Rhodesia inhabited a political reality whose permanence and ethos was very specific to a certain time and place in history, it is entirely possible that a certain complacency about the future would have permeated the military. As such, when the time came and the world moved on to newer and more radical political concepts, Rhodesia was left behind. Because the military organizations of any country are dependent on the prevailing political and social realities, it is not surprising that, with such a short time between foundation and its greatest test, the Rhodesian Security Forces struggled as much against itself as against the tide of African liberation.

${ }^{7}$ Hoffman, Taw \& Arnold, Lessons for Contemporary Counterinsurgencies, gives an operational description of Rhodesian units involved in the conflict (RAR, RLI, SAS Selous Scouts, Greys' Scouts, BSAP, RhAF, etc.). Nowhere are the artillery or armored cars mentioned, pp. 55-57. 


\section{REFERENCES}

Public Record Office (PRO) ${ }^{1}$

\section{Cabinet Documents}

CAB 8/55 Memorandum 638-M, Report of Defense

Commission on Northern Rhodesia. (1931)

CAB 10/9 Minute No. 305, Cooperation of Southern Rhodesia in Imperial Defense. (1938)

CAB 10/9 Minute No. 300, Closer Cooperation or Association of Southern Rhodesia, Northern Rhodesia and Nyasaland. (1938)

CAB 21/642 Southern Rhodesia Defense Questions. (1936)

CAB 16/117 Southern Rhodesia Contribution of Imperial Defense. (1934)

Colonial Office Documents

$\mathrm{CO} 820 / 34 / 13$ Inspector-General's Report on the Northern Rhodesia Regiment. (1938)

Dominion Office Documents

DO 119/1048 Commonwealth Defense Co-operation: visit of Sir Maurice Hankey to Dominions. (1934)

DO 119/1114 South African co-operation with other African countries on outbreak of war. (1939)

DO 119/1134 Political and Military Affairs: Reports for Middle East. (1940)

\footnotetext{
${ }^{1}$ The Public Record Office in London contains the national archives for England and Wales.
} 
War Office Documents

WO 32/14147 Bill to amend the Southern Rhodesia Defense Act. (1951-52)

WO 32/14148 Bill to amend the Southern Rhodesia Defense Act. (1939)

WO 32/14149 Bill to amend the Southern Rhodesia Defense Act. (1932)

WO 32/14150 Southern Rhodesia Defense Bill. (1930)

WO 32/14151 Southern Rhodesia Defense Bill. (1926)

WO 32/14152 Proposed reorganization of BSA Police \& Defense Forces of Southern Rhodesia. (1925-26)

Books \& Publications

A Brief History of the Rhodesia Army, City Printers, Salisbury, 1968.

Brelsford, W.V. (Ed.), Handbook to the Federation of Rhodesia and Nyasaland, Cassell \& Company, Ltd., London, 1960.

Brelsford, W.V. (Ed.), The Story of the Northern Rhodesia Regiment, The Government Printer, Lusaka, 1954.

Campbell, Sir Guy, The Charging Buffalo, A History of the Kenya Regiment, Secker \& Warburg, 1986.

Chanock, Martin, Unconsummated Union; Britain, Rhodesia and South Africa, 1900-1945, Manchester University Press, 1977.

Clayton, Anthony \& David Killingray, Khaki and Blue: Military and Police in British Colonial Africa, Center for International Studies, Ohio University, 1989.

Cole, Barbara, The Elite, The Story of the Rhodesian Special Air Service, Three Knights Publishing, Transkei, 1984.

Davenport, T.R.H., South Africa, A Modern History, Macmillan, South Africa Ltd., Johannesburg, 1980. 
Di Perna, Anthony, A Right to be Proud, Books of Rhodesia, Bulawayo, 1978.

Faber, Harold (Ed.) Luftwaffe, An analysis by former Luftwaffe generals, Sidgwick \& Jackson, London, 1979.

Gann, L.H., A History of Northern Rhodesia; Early Days to 1953, Chatto \& Windus, London, 1964.

Gann, L.H., A History of Southern Rhodesia; Early Days to 1934, Chatto \& Windus, London, 1965.

Gann, L.H., From Ox Wagon to Armored Car in Rhodesia, Military Review, April 1968.

Gibbs, Peter, The History of the BSAP, Vol. 2, Kingstons Ltd., Salisbury, 1974.

Haywood, A. \& F.A.S. Clarke, The History of the Royal West African Frontier Force, Gale \& Polden, Aldershot, 1964.

Hoffman, Bruce, \& Jennifer M. Taw, \& David Arnold, Lessons for Contemporary Counterinsurgencies, the Rhodesian Experience, RAND Corporation, Santa Monica, California, 1991.

Huxley, Elspeth, White Man's Country, Lord Delamere and the Making of Kenya, Vol. 1 \& 2, Chatto \& Windus, London, 1980.

Hyam, Ronald, The Failure of South African Expansion, 1908-1948, Macmillan Press, Ltd., 1972.

Jenner, Robin \& David List, The Long Range Desert Group, Osprey Publishing Ltd., London, 1983.

Kemp, Anthony, The SAS at War, 1941-1945, Penguin Books Ltd., London, 1991.

Kumar, Ravinder, India and the Persian Gulf Region, 1858-1907, Asia Publishing House, London, 1965.

Lloyd-Owen, Maj. Gen. D.L., Providence Their Guide, The Long Range Desert Group 1940-45, The Battery Press, Nashville, 1981.

Lunt, James, Imperial Sunset: Frontier Soldiering in the 20th Century, 
Macdonald, London, 1981.

MacDonald, J.F., The War History of Southern Rhodesia, 1939-45, Vol. 1, Southern Rhodesia Government Stationary Office, Salisbury, 1947.

MacDonald, J.F., The War History of Southern Rhodesia, 1939-45, Vol. 2 , Southern Rhodesia Government Stationary Office, Salisbury, 1950 .

McLaughlin, Peter, The Thin White Line: Rhodesia's Armed Forces since the Second World War, Zambezia, Vol. VI (ii), Salisbury, 1978.

McLaughlin, Peter, Ragtime Soldiers, The Rhodesian Experience in the First World War, Books of Zimbabwe, Bulawayo, 1980.

Miller, Charles, Battle for the Bundu, Macdonald \& Jane's, London, 1974.

Morgan, Hugh, By the Seat of Your Pants, Newton Publishers, Cowden, Kent, 1990.

Mosley, Leonard, Duel for Kilimanjaro, Weidenfeld \& Nicolson, London, 1963.

Moyse-Bartlett, H., The King's African Rifles, Gale \& Polden, Aldershot, 1956.

Owen, C., The Rhodesian African Rifles, L. Cooper, London, 1970.

Ransford, Oliver, The Rulers of Rhodesia, John Murray, London, 1968.

Rose, J.H., Newton, A.P., Benians, E.A., Ed., The Cambridge History of the British Empire, Vol 1, Cambridge University Press, 1929.

Rule, Col. Kim, The Rhodesia Native Regiment: A Battle History 19161918, Lion \& Tusk, Vol. 5, No. 1, Autumn 1993.

Shortt, James G. \& Angus McBride, The Special Air Service, Men-atArms Series No. 116, Osprey Publishing Ltd., London, 1991.

Sibley, Major J.R., Tanganyikan Guerrilla, East African Campaign 1914 1918, Ballentine Books, 1971. 
Southern Rhodesia Department of State and Public Institutions, Department of Defense, Annual Report, 1939-1945, report to the Southern Rhodesia Legislature, 1947. British Library. 